\title{
TU/e EmonOWEN

\section{Photocatalytic performance and dispersion stability of nanodispersed TiO2 hydrosol in electrolyte solutions with different cations}

Citation for published version (APA):

Wang, Z., Feng, P., Chen, H., \& Yu, Q. (2020). Photocatalytic performance and dispersion stability of nanodispersed TiO2 hydrosol in electrolyte solutions with different cations. Journal of Environmental Sciences, 88, 59-71. https://doi.org/10.1016/j.jes.2019.07.013

Document license:

TAVERNE

DOI:

10.1016/j.jes.2019.07.013

Document status and date:

Published: 01/02/2020

Document Version:

Publisher's PDF, also known as Version of Record (includes final page, issue and volume numbers)

Please check the document version of this publication:

- A submitted manuscript is the version of the article upon submission and before peer-review. There can be important differences between the submitted version and the official published version of record. People interested in the research are advised to contact the author for the final version of the publication, or visit the $\mathrm{DOI}$ to the publisher's website.

- The final author version and the galley proof are versions of the publication after peer review.

- The final published version features the final layout of the paper including the volume, issue and page numbers.

Link to publication

\footnotetext{
General rights

- You may freely distribute the URL identifying the publication in the public portal. follow below link for the End User Agreement:

www.tue.nl/taverne

\section{Take down policy}

If you believe that this document breaches copyright please contact us at:

openaccess@tue.nl

providing details and we will investigate your claim.
}

Copyright and moral rights for the publications made accessible in the public portal are retained by the authors and/or other copyright owners and it is a condition of accessing publications that users recognise and abide by the legal requirements associated with these rights.

- Users may download and print one copy of any publication from the public portal for the purpose of private study or research.

- You may not further distribute the material or use it for any profit-making activity or commercial gain

If the publication is distributed under the terms of Article $25 \mathrm{fa}$ of the Dutch Copyright Act, indicated by the "Taverne" license above, please 


\title{
Photocatalytic performance and dispersion stability of nanodispersed $\mathrm{TiO}_{2}$ hydrosol in electrolyte solutions with different cations
}

\author{
Zixiao Wang ${ }^{1,2}$, Pan Feng ${ }^{1,4, *}$, Heng Chen ${ }^{1}$, Qingliang $\mathrm{Yu}^{2,3, *}$ \\ 1. Jiangsu Key Laboratory of Construction Materials, School of Materials Science and Engineering, Southeast University, Nanjing 211189, China \\ 2. Department of the Built Environment, Eindhoven University of Technology, 5600 MB Eindhoven, the Netherlands \\ 3. School of Civil Engineering, Wuhan University, Wuhan 430072, China \\ 4. State Key Laboratory of High Performance Civil Engineering Materials, Nanjing 210008, China
}

\section{A R T I C L E I N F O}

\section{Article history:}

Received 1 April 2019

Revised 17 July 2019

Accepted 18 July 2019

Available online 26 July 2019

\section{Keywords:}

Photocatalytic oxidation

Nano dispersed $\mathrm{TiO}_{2}$ hydrosol

Aqueous inorganic cations

Stability

Photocatalytic kinetic

\begin{abstract}
A B S T R A C T
The existence of electrolytes in aquatic environment on the photocatalytic performance and coagulation of nanodispersed $\mathrm{TiO}_{2}$ hydrosol and the corresponding photocatalytic alteration were investigated by studying cations $\left(\mathrm{Na}^{+}, \mathrm{K}^{+}, \mathrm{Ca}^{2+}, \mathrm{Mg}^{2+}\right.$, and $\left.\mathrm{Al}^{3+}\right)$. The photocatalysis reactions of nano $\mathrm{TiO}_{2}$ with different dosages of electrolytes were measured by monitoring the degradation of Rhodamine $\mathrm{B}(\mathrm{RhB})$ under ultraviolet A (UV-A) irradiation over time. The results showed that the photocatalytic performance of $\mathrm{TiO}_{2}$ was improved by the presence of $\mathrm{Al}^{3+}$, while the performance was impaired by the other tested cations. The negative influences of divalent ions on the photocatalytic performance of $\mathrm{TiO}_{2}$ were more significant than monovalent ions. The $\mathrm{TiO}_{2}$ sol dispersed stable at nano scale at low concentration of electrolyte $(<0.01 \mathrm{~mol} / \mathrm{L})$ with slight change of $\mathrm{pH}$, and coagulated into micro sizes at high concentration of electrolytes $(>0.1 \mathrm{~mol} / \mathrm{L})$ with larger increase or decrease of $\mathrm{pH}$. The positive effects of $\mathrm{Al}^{3+}$ on the photodegradation rate of $\mathrm{RhB}$ might relate to the strong hydrolytic action of $\mathrm{Al}^{3+}$ in aquatic solutions. The photocatalytic processes of $\mathrm{TiO}_{2}$ in the presence of all ions followed the Langmuir-Hinshelwood model, and the reaction kinetic constant was increased with the decrease of $\mathrm{pH}$ caused by different cations. These work suggested a new perspective about the relationship between coagulation and photocatalytic performance of $\mathrm{TiO}_{2}$ hydrosols in electrolyte with hydrolysable cations, which demonstrated that $\mathrm{TiO}_{2}$ hydrosols may be suitable as photocatalysts in aquatic environments.
\end{abstract}

(c) 2019 The Research Center for Eco-Environmental Sciences, Chinese Academy of Sciences. Published by Elsevier B.V.

\section{Introduction}

The photocatalytic reaction is one of the most widely studied topics in the fine chemical industry, building materials, water and air treatment, sanitation, environmental protection, automobile industry, etc. (Bahnemann, 2004; Chen and Poon, 2009;
Hashimoto et al., 2005; Dincer, 2000; Jing et al., 2010; Malato et al., 2009; Mills and Lee, 2002; Spasiano et al., 2013). Among the photocatalysts, titanium dioxide $\left(\mathrm{TiO}_{2}\right)$ particles have received the greatest attention. The multi-faceted functional properties of $\mathrm{TiO}_{2}$, such as its chemical and thermal stability and strong mechanical properties have promoted its wide

\footnotetext{
* Corresponding authors. E-mails: pan.feng@seu.edu.cn (Pan Feng), q.yu@bwk.tue.nl (Qingliang Yu).
} 
application in various fields like water treatment, air purification, etc. (Chong et al., 2010). Nanodispersed $\mathrm{TiO}_{2}$ hydrosols are known to contain mainly anatase nano particles and are aggregation-stable even at high concentrations of dispersed phase and electrolytes mainly refer to strong acid solutions, which means the surface charge of nanodispersed $\mathrm{TiO}_{2}$ hydrosol particles is normally positive (Abbas et al., 2011; Alphonse et al., 2010; Ghenne et al., 1998; Pavlova-Verevkina et al., 2003,2005; Santacesaria et al., 1986). In the field of photocatalytic degradation of organic pollutants, hydrosol catalysts can be easily separated, collected and re-dispersed for continuous reuse because of its sensitivity to $\mathrm{pH}$ value and electrolyte strength of medium (Ghenne et al., 1998; Leroy et al., 2011; Pavlova-Verevkina et al., 2003, 2005, 2007; Santacesaria et al., 1986). Moreover, some research results show nanodispersed $\mathrm{TiO}_{2}$ hydrosols exhibit high photochemical reactivity even superior to nano $\mathrm{TiO}_{2}$ powders (Liu et al., 2008; Yu et al., 2010).

However, agglomeration and coagulation are the main physicochemical processes affecting the photocatalytic performance of nanodispersed $\mathrm{TiO}_{2}$ hydrosols or nano powders (Brunelli et al., 2013). The cations like Fe ${ }^{3+}$ (Wang et al., 2008) would improve the efficiency of photocatalytic oxidation of $\mathrm{TiO}_{2}$ hydrosols in solutions by influencing the complex hydroxyl groups bond between $\mathrm{TiO}_{2}$ surface and $\mathrm{Fe}^{3+}$. Volkova et al. $(2012,2010)$ had studied the coagulation properties and fractionation of $\mathrm{TiO}_{2}$ hydrosol in haloid salts solutions, and the results supported that the sol stability was strongly affected by the coion (refers to cation) nature and valence.

Compared with nanodispersed $\mathrm{TiO}_{2}$ hydrosols, the stability of nano $\mathrm{TiO}_{2}$ powders influenced by inorganic cations in aquatic environments (Chen et al., 2012, 1997; Fu et al., 2005; Hotze et al., 2010; Terzian et al., 1991; Yang et al., 2010) has been studied relatively comprehensive. Common cations such as $\mathrm{Na}^{+}$(French et al., 2009), Ca ${ }^{2+}$ (French et al., 2009; Zhang et al., 2009) and $\mathrm{Mg}^{2+}$ (Loosli et al., 2015) were found to enhance agglomeration and sedimentation of nano $\mathrm{TiO}_{2}$ particles by absorbing on the surface of particles surfaces, and the enhancement of divalent cations were greater because of the higher negative charge. For nano $\mathrm{TiO}_{2}$ powders, aluminum salts, like $\mathrm{Al}_{2}\left(\mathrm{SO}_{4}\right)_{3}, \mathrm{Al}_{2} \mathrm{O}_{3}$, were usually used as the coagulants to remove the particles during the primary water treatment (Honda et al., 2014; Xu et al., 2014). Some heavy cations, like $\mathrm{Cu}^{2+}$ (Đukić et al., 2015; Kanna et al., 2005), $\mathrm{Pb}^{2+}$ (Đukić et al., 2015; Islam et al., 2010; Kanna et al., 2005), $\mathrm{Fe}^{3+}$ (Kanna et al., 2005), $\mathrm{Mn}^{2+}$ (Đukić et al., 2015; Kanna et al., 2005) and $\mathrm{Zn}^{2+}$ (Đukić et al., 2015; Kanna et al., 2005), can absorb on the surface of nano $\mathrm{TiO}_{2}$ powders in aquatic solutions, because of the deprotonated surface hydroxyls yield negatively-charged surface of nano $\mathrm{TiO}_{2}$ powders. Due to the increasing application of $\mathrm{TiO}_{2}$ catalyst for obtaining functional cement-based materials, the influences of Portland cement-like ionic environment on the surface chemical of nano $\mathrm{TiO}_{2}$ powders had been studied in some researches (Folli et al., 2010; Yousefi et al., 2013).

Since the synthesis processes of nanodispersed $\mathrm{TiO}_{2}$ hydrosols and nano $\mathrm{TiO}_{2}$ powders are different, their phase, disperse composition and condition are totally different (PavlovaVerevkina et al., 2003). For example, heat treatment is a requirement for synthesizing crystallized nano $\mathrm{TiO}_{2}$ powders by sol-gel method, which causes the irreversible aggregation of particles. Namely, it is difficult to obtain nanodispersed systems by re-dispersing nano $\mathrm{TiO}_{2}$ powders because of the initial aggregation of particles. Moreover, the particles surfaces in nano dispersed $\mathrm{TiO}_{2}$ hydrosols are normally positive, while the particle surfaces in nano $\mathrm{TiO}_{2}$ powders aqueous suspensions are normally negative. Thus, the interaction mechanism between the cations and $\mathrm{TiO}_{2}$ particles studied in literatures via nano $\mathrm{TiO}_{2}$ powders can hardly explain the influence of cations to $\mathrm{TiO}_{2}$ particles in nanodispersed hydrosol systems. In addition, few studies focus on the photochemical reactivity of nanodispersed $\mathrm{TiO}_{2}$ hydrosols in aqueous solutions contaminated by cations with different valence. According to literature (Volkova et al., 2012, 2010; Zhang et al., 2018), the effect of certain cations on the coagulation of $\mathrm{TiO}_{2}$ hydrosol particles is very pronounced, and the effect is closely related to the valance of cations and the $\mathrm{pH}$ of the aquatic systems.

The goal of this study was to investigate the probable relationship between photocatalytic property and stability of $\mathrm{TiO}_{2}$ hydrosol with different kinds of inorganic cations. Ghenne et al. (1998) reported that in acidic media, the critical coagulation concentration of anions of $\mathrm{NO}_{3}^{-}$and $\mathrm{Cl}^{-}$was nearly $0.5 \mathrm{~mol} / \mathrm{L}$ at $\mathrm{pH}=2$, and the critical coagulation concentration of anions decreased with the increase of $\mathrm{pH}$ values. Budarz et al. (2017) showed that the adverse impacts of $\mathrm{NO}_{3}^{-}$on the photocatalytic property of nano $\mathrm{TiO}_{2}$ are less than that of $\mathrm{Cl}^{-}$ in aqueous solutions. Therefore, in this work, the aqueous solutions of $\mathrm{Na}^{+}, \mathrm{K}^{+}, \mathrm{Ca}^{2+}, \mathrm{Mg}^{2+}$ and $\mathrm{Al}^{3+}$ with a concentration of $0.005-0.5 \mathrm{~mol} / \mathrm{L}$ were chosen as the tested cations, and $\mathrm{NO}_{3}^{-}$ was selected as the anion in this study. The photocatalytic activity of nanodispersed $\mathrm{TiO}_{2}$ hydrosol was assessed by the photodegradation performance on Rhodamine $B(R h B)$. The stability of particles in hydrosol over time was evaluated by the particle size and zeta potential values.

\section{Materials and methods}

\subsection{Reagents and solutions}

$\mathrm{NaNO}_{3}, \mathrm{KNO}_{3}, \mathrm{Ca}\left(\mathrm{NO}_{3}\right)_{2}, \mathrm{Mg}\left(\mathrm{NO}_{3}\right)_{2}$ and $\mathrm{Al}\left(\mathrm{NO}_{3}\right)_{3}$ and $\mathrm{RhB}$ were analytical pure commercial regents and applied without further purification. Solutions of salts $(0.005,0.1$, and $0.5 \mathrm{~mol} / \mathrm{L}$ ) were prepared with deionized (DI) water. A $30 \mathrm{mg} / \mathrm{L}$ RhB solution was prepared as the target pollutant in the test. The solid content of the commercial nano anatase $\mathrm{TiO}_{2}$ was $10 \%$ in this hydrosol, the $\mathrm{pH}$ was 1.17 at $20^{\circ} \mathrm{C}$ and the mean particle size was $30.3 \mathrm{~nm}$. In order to purify the $\mathrm{TiO}_{2}$ hydrosol, the commercial $\mathrm{TiO}_{2}$ hydrosol was filtrated by an ultrafiltration system for 10 cycles, and the $80 \mathrm{~mm} 100 \mathrm{kDa}$ ultrafiltration membranes were used to remove the impurities. After purification, the $\mathrm{pH}$ of hydrosol was 2.32 at $20^{\circ} \mathrm{C}$ and the mean particle size was $37 \mathrm{~nm}$. The detail method of $\mathrm{TiO}_{2}$ purification can be find in supporting information.

\subsection{Degradation experiments}

The photocatalytic performance of $\mathrm{TiO}_{2}$ was evaluated by examining the degradation of $50 \mathrm{~mL}$ solution with the initial $\mathrm{RhB}$ concentration of $30 \mathrm{mg} / \mathrm{L}$ under ultraviolet (UV) illumination. A $400 \mathrm{~W}$ ultraviolet metal halogen lamp (UV-400, Shanghai Libi Company of Vacuum Technique, China) was used 
as the source of the UV irradiation light. The UV lamp was placed outside the reactor and the distance between the lamp and the reactor was $10 \mathrm{~cm}$, the wavelength $(\lambda)$ of the ultraviolet lamp ranges from 253.7 to $600 \mathrm{~nm}$ (centered at $\lambda=365 \mathrm{~nm}$ ). The intensity of the UV light was $34.9 \mathrm{~mW} / \mathrm{cm}^{2}$. The $2 \mathrm{~g} / \mathrm{L} \mathrm{TiO}$ and $30 \mathrm{mg} / \mathrm{L}$ RhB solution were put into the reactor and mixed with a magnetic stirrer at $400 \mathrm{r} / \mathrm{min}$ during the test. The UV lamp was turned on after the 30 min adsorption-desorption equilibrium at dark. The UV light and the reactor were both inside the intelligent artificial climate box (PRX-350C, Saifu Experimental Apparatus Technology Company, China), by which the test temperature was controlled at $25 \pm 2^{\circ} \mathrm{C}$. A $4.5 \mathrm{~mL}$ aliquot was sampled every $5 \mathrm{~min}$; it was centrifuged for $5 \mathrm{~min}$ at 10,000 r/min and then filtered through a nylon syringe membrane filter with pore size of $0.45 \mu \mathrm{m}$ (BS-QT-014, Biosharp, Japan) prior to analysis. Variations in the concentration of $\mathrm{RhB}$ in each degraded solution were monitored by UV-visible spectroscopy (UV-Vis) (UV-2600 spectrophotometer, Shimadzu, Japan). There are two different photodegradation processes of $\mathrm{RhB}$, photobleaching and $\mathrm{N}$ deethylation (Wu et al., 1998). With the increased radiation time, the N-deethylation of $\mathrm{RhB}$ causes the blue shift in the maximum absorption of the dye solution, and then absorption peak disappears rapidly after the N-deethylation (Qu et al., 1998). The photocatalytic oxidation rate of $\mathrm{TiO}_{2}$ can be represented by the absorption of $\mathrm{RhB}$ at $554 \mathrm{~nm}$, and can be calculated by the following formula (Kansal et al., 2007):

$R=\frac{C_{0}-C_{t}}{C_{0}} \times 100 \%$

where, $R$ is the photo-degradation rate of $R h B, C_{0}(g / L)$ is the initial absorption of $\mathrm{RhB}$ at $554 \mathrm{~nm}$ before the illumination, and $C_{t}(g / L)$ is the absorption of $\mathrm{RhB}$ at $554 \mathrm{~nm}$ at different illumination time.

\subsection{Dispersion stability}

Laser particle sizer (Microtrac S3500, Microtrac Inc., USA) was used to measure nano $\mathrm{TiO}_{2}$ aggregate size. Time-resolved size measurements, reported in terms of median diameter (D50), were taken every $2 \mathrm{~min}$ for $30 \mathrm{~min}$. To characterize the dispersion stability of nano $\mathrm{TiO}_{2}$, zeta potential of the Nanoparticles was measured by electroacoustic zeta potentiometer at each test time point (DT-310, Dispersion Technology Instrument, USA).

\section{Results and discussion}

\subsection{Effect of cations on the photocatalytic degradation}

Fig. 1 shows the photo-degradation rate of $\mathrm{RhB}$ in all the solutions over time. It can be seen that the degradation rate of pure $\mathrm{TiO}_{2}$ hydrosol was $86.06 \%$ during the first $15 \mathrm{~min}$, which was higher than that of $\mathrm{TiO}_{2}$ in monovalent and bivalent cationic solutions. After $20 \mathrm{~min}$ illuminating, the photodegradation rates of $\mathrm{RhB}$ in all electrolyte solutions were very close and the rate values were higher than $95 \%$. The photodegradation rate of $\mathrm{RhB}$ decreased with the increase of monovalent and bivalent cation contents. But in the $\mathrm{Al}\left(\mathrm{NO}_{3}\right)_{3}$ solutions, the photo-degradation rate showed different results.
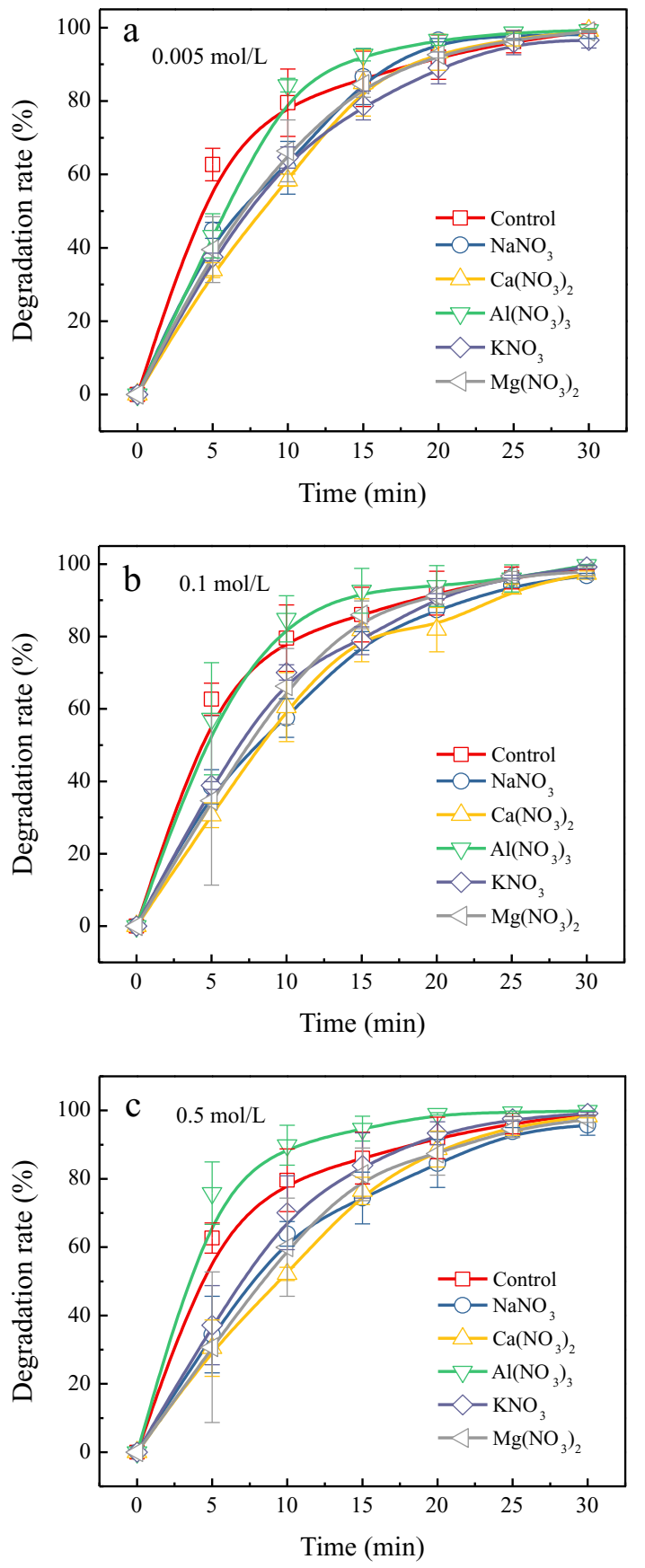

Fig. 1 - Photodegradation rate of Rhodamine $B(\mathrm{RhB})$ in solution within $30 \mathrm{~min}$ at (a) $0.005 \mathrm{~mol} / \mathrm{L}$, (b) $0.1 \mathrm{~mol} / \mathrm{L}$ and (c) $0.5 \mathrm{~mol} / \mathrm{L}$ cations.

The photo-degradation rate of $\mathrm{RhB}$ increased with the increase of $\mathrm{Al}\left(\mathrm{NO}_{3}\right)_{3}$ contents, and the rate values were higher than that in pure $\mathrm{TiO}_{2}$ hydrosol after 10 min illumination.

\subsection{Coagulation of $\mathrm{TiO}_{2}$ particles}

Due to $\mathrm{TiO}_{2}$ hydrosol consisting of anatase nanoparticles are stable to disperse at high concentration and certain electrolytes and certain $\mathrm{pH}$ range, the stability of $\mathrm{TiO}_{2}$ hydrosols caused by 

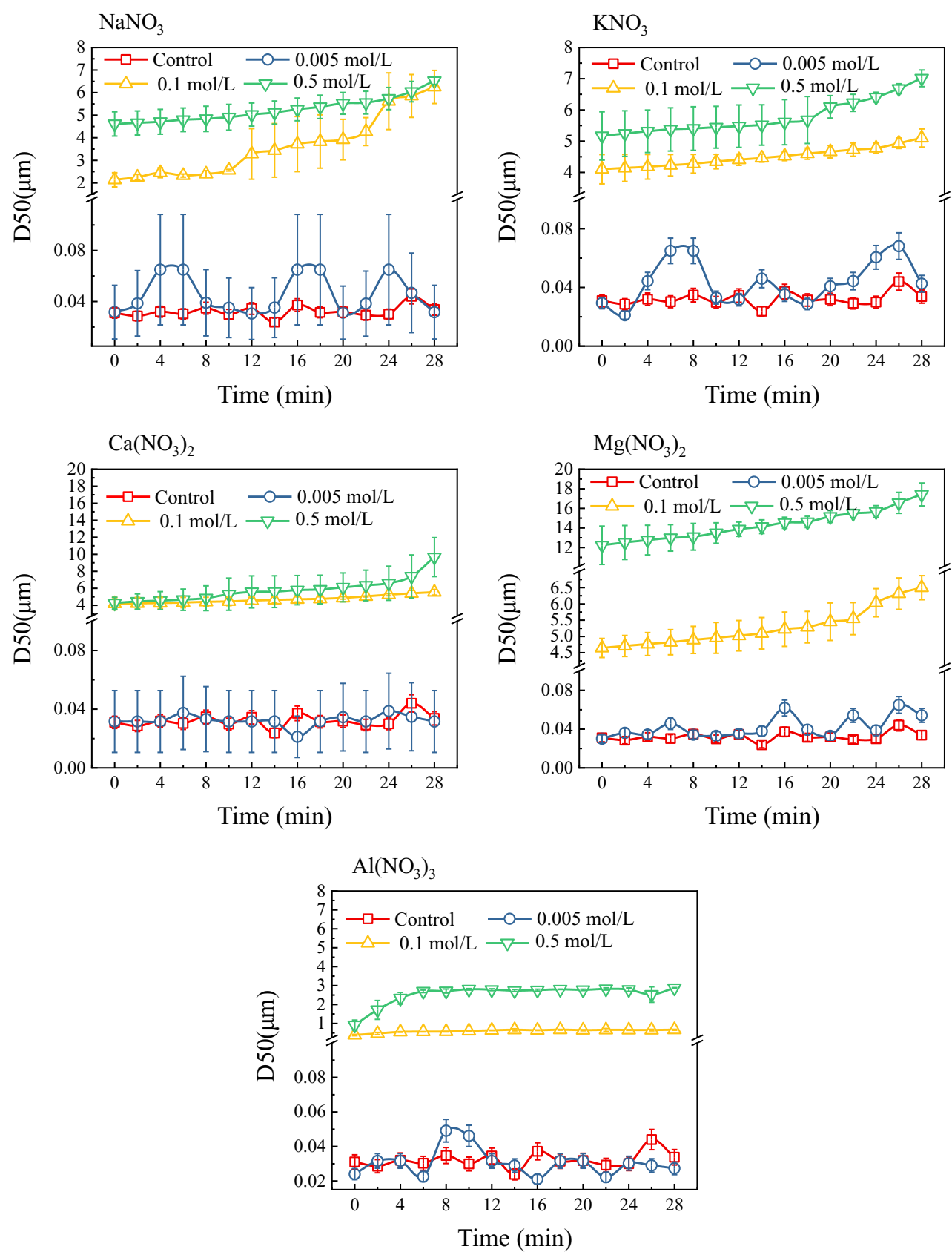

Fig. 2 - Median diameter (D50) of $\mathrm{TiO}_{2}$ particles in electrolytes over $30 \mathrm{~min}$ in the presence of $\mathrm{NaNO}_{3}, \mathrm{KNO}_{3}, \mathrm{Ca}\left(\mathrm{NO}_{3}\right)_{2}, \mathrm{Mg}\left(\mathrm{NO}_{3}\right)_{2}$, and $\mathrm{Al}\left(\mathrm{NO}_{3}\right)_{3}$.

electrolytes has been studied both experimentally and theoretically (Pavlova-Verevkina et al., 2007, 2003; Volkova et al., 2012, 2010). In most of studies, the optical density increment is chosen as the evaluation index for the stability of $\mathrm{TiO}_{2}$. Moreover, the photocatalytic oxidation process is related to the production and annihilation of electrons and holes, which are influenced by the particle size of $\mathrm{TiO}_{2}$ in electrolyte solutions. To represent the stability of $\mathrm{TiO}_{2}$ hydrosols in electrolytes intuitively, the particle sizes during coagulation process are measured in this work.

Fig. 2 shows $\mathrm{D} 50$ of the nano $\mathrm{TiO}_{2}$ in different electrolytes over $30 \mathrm{~min}$. In the presence of $\mathrm{NaNO}_{3}$ and $\mathrm{KNO}_{3}$, the particle size of nano $\mathrm{TiO}_{2}$ was comparable with the initial nano $\mathrm{TiO}_{2}$ size at $0.005 \mathrm{~mol} / \mathrm{L}$. The aggregated particle size increased to 2.0 and $7.0 \mu \mathrm{m}$ at 0.1 and $0.5 \mathrm{~mol} / \mathrm{L}$, respectively. In the presence of $\mathrm{Ca}\left(\mathrm{NO}_{3}\right)_{2}$ and $\mathrm{Mg}\left(\mathrm{NO}_{3}\right)_{2}$, the particle sizes of nano $\mathrm{TiO}_{2}$ were also comparable with the initial nano $\mathrm{TiO}_{2}$ size at $0.005 \mathrm{~mol} / \mathrm{L}$, then the particle sizes increased to around 5.0 and $11.0 \mu \mathrm{m}$ at 0.1 and $0.5 \mathrm{~mol} / \mathrm{L}$, respectively. In the presence of $\mathrm{Al}\left(\mathrm{NO}_{3}\right)_{3}$, the particle size of nano $\mathrm{TiO}_{2}$ was comparable with the initial Nano $\mathrm{TiO}_{2}$ size at $0.005 \mathrm{~mol} / \mathrm{L}$, and the particle size increased and stayed around 0.5 and $3.0 \mu \mathrm{m}$ at 0.1 and $0.5 \mathrm{~mol} / \mathrm{L}$, respectively. These results were consistent with the results in literature (Volkova et al., 2012) that the optical density of $\mathrm{TiO}_{2}$ sols remains 
unchanged at low concentration $\left(\leq 10^{-2} \mathrm{~mol} / \mathrm{L}\right)$ of coagulants (haloids) and increase begins from the coagulants concentration of $0.03 \mathrm{~mol} / \mathrm{L}$. The ion-electrostatic repulsive forces between $\mathrm{TiO}_{2}$ particles contributed to the stability of sols in the low concentrations.

Significantly, the aggregate sizes of sols in $\mathrm{Al}\left(\mathrm{NO}_{3}\right)_{3}$ solution were obviously smaller than that in $\mathrm{Ca}\left(\mathrm{NO}_{3}\right)_{2}$ and $\mathrm{Mg}\left(\mathrm{NO}_{3}\right)_{2}$ solutions at 0.1 and $0.5 \mathrm{~mol} / \mathrm{L}$. In addition, the aggregate sizes in $0.5 \mathrm{~mol} / \mathrm{L} \mathrm{Al}\left(\mathrm{NO}_{3}\right)_{3}$ solution were smaller than $4.0 \mu \mathrm{m}$, while the sizes in $\mathrm{Ca}\left(\mathrm{NO}_{3}\right)_{2}$ solution were between 4.0 and $11.0 \mu \mathrm{m}$ and in $\mathrm{Mg}\left(\mathrm{NO}_{3}\right)_{2}$ solution were between 12.0 and $18.0 \mu \mathrm{m}$.

\subsection{Zeta potential of $\mathrm{TiO}_{2}$ and $\mathrm{pH}$ in solutions}

Zeta potential is a physicochemical parameter of particular importance in describing the ion adsorption and electrostatic interactions between charged particles (Leroy et al., 2011), which reflect the dispersion-agglomeration properties of nanoparticles in aqueous media. Since the $\mathrm{pH}$ of solutions significantly affects the stability of $\mathrm{TiO}_{2}$ hydrosols, monitoring the $\mathrm{pH}$ changing of solutions over time is helpful for evaluating the stability of sols.
The zeta potential of nano $\mathrm{TiO}_{2}$ and the $\mathrm{pH}$ changes of electrolytes are shown in Fig. 3. It can be seen that the zeta potential of nano $\mathrm{TiO}_{2}$ in the control group was about $60 \mathrm{mV}$, and the $\mathrm{pH}$ value was about 3.0. When the electrolytes content was $0.005 \mathrm{~mol} / \mathrm{L}$, the zeta potential of $\mathrm{TiO}_{2}$ in $\mathrm{NaNO}_{3}, \mathrm{KNO}_{3}$, $\mathrm{Mg}\left(\mathrm{NO}_{3}\right)_{2}, \mathrm{Ca}\left(\mathrm{NO}_{3}\right)_{2}$ and $\mathrm{Al}\left(\mathrm{NO}_{3}\right)_{3}$ solutions decreased to around 30, 41, 27, 37 and $43 \mathrm{mV}$, respectively. When the salt content was $0.1 \mathrm{~mol} / \mathrm{L}$, the zeta potential of $\mathrm{TiO}_{2}$ in $\mathrm{NaNO}_{3}$, $\mathrm{KNO}_{3}, \mathrm{Mg}\left(\mathrm{NO}_{3}\right)_{2}, \mathrm{Ca}\left(\mathrm{NO}_{3}\right)_{2}$ and $\mathrm{Al}\left(\mathrm{NO}_{3}\right)_{3}$ solutions increased by $85.94 \%, 35.15 \%, 60.17 \%, 89.85 \%$ and $0.91 \%$ of the initial value, respectively. When the salt content was $0.5 \mathrm{~mol} / \mathrm{L}$, the zeta potentials of that were grown by $180.56 \%, 55.63 \%, 133.68 \%$, $38.91 \%$, and $4.91 \%$ of the initial value, respectively. These results revealed that in the presence of $\mathrm{Al}^{3+}$, the zeta potential of $\mathrm{TiO}_{2}$ did not change significantly over time that meant the interaction between nanoparticles was relatively limited.

It is clear that the $\mathrm{pH}$ values of solutions during the $30 \mathrm{~min}$ test were stable in each cation contents. As to $\mathrm{Al}\left(\mathrm{NO}_{3}\right)_{3}$ solutions, the $\mathrm{pH}$ of the solutions decreased with the contents of aluminum ion and the zeta potential of $\mathrm{TiO}_{2}$ was relatively stable. In the presence of $\mathrm{Na}^{+}$and $\mathrm{K}^{+}$, when the electrolytes contents increased from 0 to $0.5 \mathrm{~mol} / \mathrm{L}$. Fig. $3 \mathrm{a}$ and $\mathrm{b}$ shows that the $\mathrm{pH}$ values of solutions increased from 3.0 to about 3.6.
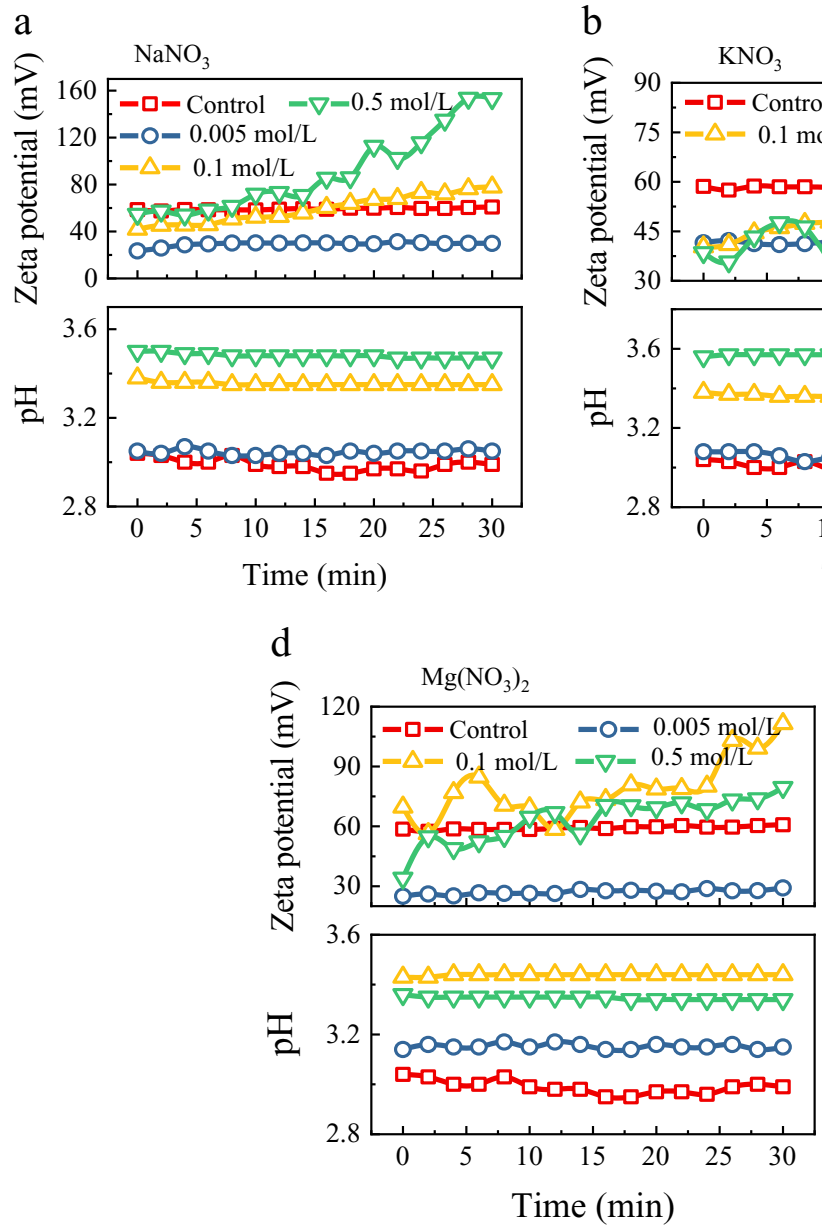
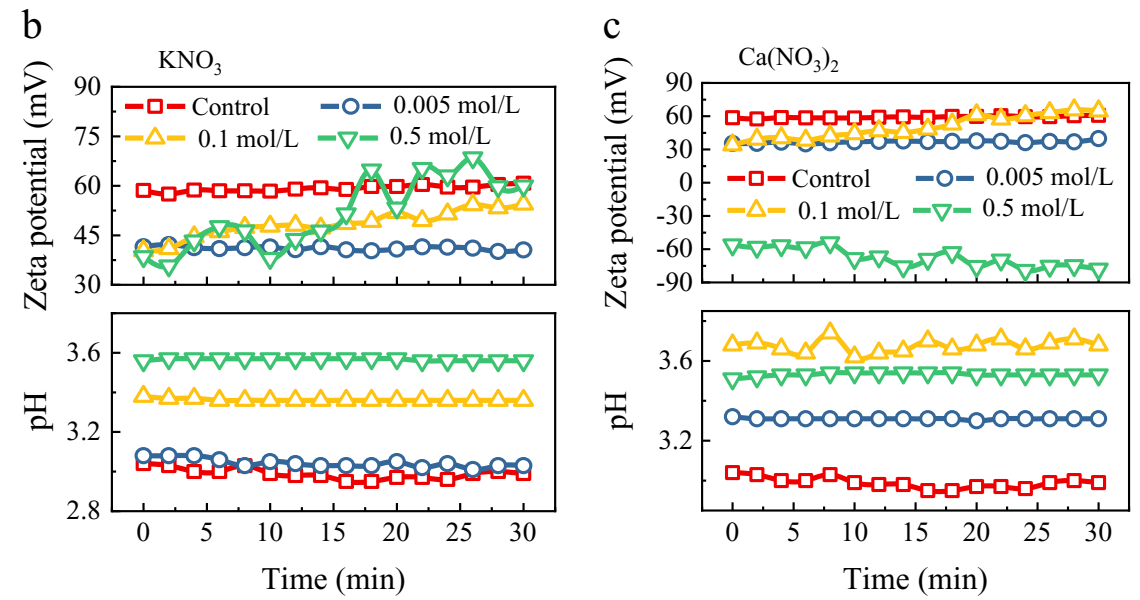

Fig. 3 - Zeta potential of $\mathrm{TiO}_{2}$ and the $\mathrm{pH}$ of solution over $30 \mathrm{~min}$ in the presence of (a) $\mathrm{NaNO}_{3},(\mathrm{~b}) \mathrm{KNO}_{3},(\mathrm{c}) \mathrm{Ca}\left(\mathrm{NO}_{3}\right)_{2},(\mathrm{~d}) \mathrm{Mg}$ $\left(\mathrm{NO}_{3}\right)_{2},(\mathrm{e}) \mathrm{Al}\left(\mathrm{NO}_{3}\right)_{3}$. 
Fig. $3 \mathrm{c}$ and $\mathrm{d}$ shows that in the presence of $\mathrm{Ca}^{2+}$ and $\mathrm{Mg}^{2+}$, the $\mathrm{pH}$ values increased from 3.0 to about 3.6 when the metal ion contents increased from 0 to $0.1 \mathrm{~mol} / \mathrm{L}$, then the $\mathrm{pH}$ values decreased slightly when the metal ions content increased to $0.5 \mathrm{~mol} / \mathrm{L}$. As to $\mathrm{Al}^{3+}$, Fig. 3e shows that the $\mathrm{pH}$ of solutions decreased obviously from about 3.0 to about 2.0, when the electrolyte contents increased from 0 to $0.5 \mathrm{~mol} / \mathrm{L}$.

It is worth mentioning that in the $\mathrm{pH}$ range of 2.0-4.0, according to the study of Ghenne et al. (1998), the critical coagulation concentration of $\mathrm{NO}_{3}^{-}$affecting $\mathrm{TiO}_{2}$ hydrosol is less than $0.5 \mathrm{~mol} / \mathrm{L}$. However, in the presence of $0.5 \mathrm{~mol} / \mathrm{L} \mathrm{Al}$ $\left(\mathrm{NO}_{3}\right)_{3}$, the $\mathrm{D} 50$ of $\mathrm{TiO}_{2}$ particles were not larger than those in other electrolyte solutions and the photo-degradation of $\mathrm{RhB}$ is the highest. As a result, the influence of $\mathrm{Al}^{3+}$ on the photocatalytic performance and stability in aquatic system needs further discussion.

\subsection{Relationship between photocatalysis, coagulation of $\mathrm{TiO}_{2}$ hydrosol and cations}

\subsubsection{Explanations in terms of photocatalytic kinetics}

According to previous research (Chen and Ray, 1998; Galindo et al., 2001; Lee et al., 1999; Poulios and Aetopoulou, 1999; Poulios and Tsachpinis, 1999), the influence of the initial concentration of the solute on the photocatalytic degradation rate of most organic compounds is described by a pseudofirst-order kinetics, which is rationalized in terms of the Langmuir-Hinshelwood model (LH model), modified to accommodate reactions occurring at a solid-liquid interface (Sauer et al., 2002).

Fig. 4 shows the reaction rate kinetics in different cationic nitrate solutions. The slope values of the fitting equations were the $k_{\text {app }}$ (the apparent first-order rate constant) that are shown in Table 1. From Fig. 4, the LH model fits the experimental data very well $\left(R^{2}>0.950\right)$. The high $R^{2}$ values indicate that the LH model is appropriate for describing the $\mathrm{RhB}$ oxidation in cationic nitrate solutions, which meant the reaction rate was mainly controlled by the concentration of the reactants rather than the irradiation intensity or time. From Table 1, it can be seen that the $k_{\text {app }}$ of the control group was $0.158 \mathrm{~min}^{-1}$, and the $k_{\text {app }}$ values decreased with the contents of cations except for the aluminum. The $k_{\text {app }}$ values for sodium and potassium were similar, and the $k_{\text {app }}$ values for magnesium at high contents ( 0.1 and $0.5 \mathrm{~mol} / \mathrm{L}$ ) were higher than that for calcium. Fig. 4 e shows that the $k_{\text {app }}$ values at $0.005,0.1$ and $0.5 \mathrm{~mol} / \mathrm{L}$ were $0.178,0.194$ and $0.215 \mathrm{~min}^{-1}$ respectively, and indicated a greater reaction rate of the photo-degradation process.

As seen from Table 2 , the $k_{\text {app }}$ reported in literatures showed that the $k_{\text {app }}$ for nano $\mathrm{TiO}_{2}$ powders degradation of $\mathrm{RhB}$ was lower than $0.1 \mathrm{~min}^{-1}$, even for some surface modified nano $\mathrm{TiO}_{2}$ powders. In this study, the $k_{\mathrm{app}}$ of $\mathrm{TiO}_{2}$ hydrosol (10 wt.\%) without cations was $0.158 \mathrm{~min}^{-1}$, which was more than 10 times higher than the results in literatures mentioned in Table 2. The re-dispersion of nano $\mathrm{TiO}_{2}$ powders in aqueous solution is still a thorny problem. There is no doubt that the nano $\mathrm{TiO}_{2}$ particles were agglomerated irreversibly during the drying process of producing nano $\mathrm{TiO}_{2}$ powders. This instinctive agglomeration is one of the main reasons for the low photocatalytic performance of nano $\mathrm{TiO}_{2}$ powders in aquatic environments. According to Fig. 2, the $\mathrm{D} 50$ of $\mathrm{TiO}_{2}$ in control group was nearly $35 \mathrm{~nm}$ during the irradiation in $30 \mathrm{~min}$, the better dispersity in aqueous solution of $\mathrm{TiO}_{2}$ hydrosol tested in this study could explain the higher $k_{\text {app }}$ and shorter half period of RhB degradation.

According to the test results about $\mathrm{D} 50$ of $\mathrm{TiO}_{2}$ particles and degradation of $\mathrm{RhB}$ in this study, these explanations can partly interpret the inhibition of $\mathrm{Na}^{+}, \mathrm{K}^{+}, \mathrm{Ca}^{2+}$ and $\mathrm{Mg}^{2+}$. Due to the aggregation of $\mathrm{TiO}_{2}$ particles in the presence of these cations, the photocatalytic activity of $\mathrm{TiO}_{2}$ was hindered and the degradation of $\mathrm{RhB}$ was decreased. However, these explanations cannot explain the acceleration effect of $\mathrm{Al}^{3+}$ on the degradation of $\mathrm{RhB}$, because the agglomeration is also measured when the content of $\mathrm{Al}^{3+}$ is higher than $0.1 \mathrm{~mol} / \mathrm{L}$.

\subsubsection{Explanations in terms of spectroscopy}

As reported in the literature (Ortelli et al., 2014), the degradation mechanism of $\mathrm{RhB}$ caused by nano $\mathrm{TiO}_{2}$ is proposed as two ways, one way is de-ethylation process that has been reported in other studies (Qu et al., 1998; Wu et al., 1998), another way is the degradation process of the chromophore structure. The changing trend of UV-Vis spectra of RhB in five kinds of electrolyte was similar in the test, to reduce the space, the groups in $\mathrm{Al}\left(\mathrm{NO}_{3}\right)_{3}$ solutions were taken as the analysis example. Other spectra images can be found in Appendix A. Supplementary data.

The UV-Vis absorption spectra of nano $\mathrm{TiO}_{2}$ powder degrading RhB have been studied in several reports (Lei et al., 2012; Wahyuningsih et al., 2014; Wang and Zhang, 2011; Wang et al., 2009; Zhao et al., 1998; Zhu et al., 2014). In these literatures, the absorbing peak values at the range of 230-270 nm in the spectra of nano $\mathrm{TiO}_{2}$ powder degrading $\mathrm{RhB}$ were smaller than the peak values at $554 \mathrm{~nm}$, and there was only one peak at the range of 200-350 $\mathrm{nm}$. While, in this study, Fig. 5 shows the UV-Vis spectra of RhB collected during $30 \mathrm{~min}$ of irradiation at $\mathrm{Al}\left(\mathrm{NO}_{3}\right)_{3}$ solutions. Deethylation of RhB causes a blue shift of the main absorption band at visible light range, as can be seen in Fig. 5, the main absorption spectra of $\mathrm{RhB}$ decreased rapidly with the blue shift over irradiation time. The main absorption band at $554 \mathrm{~nm}$ is due to the chromophore structure, like $\mathrm{C}=\mathrm{N}$ and $\mathrm{C}=\mathrm{O}$, of $\mathrm{RhB}$, and the wide and strong absorption band in $230-270 \mathrm{~nm}$ is due to the benzene rings of RhB. The results showed that in the relatively low concentration $(\leq 0.01 \mathrm{~mol} / \mathrm{L})$ of electrolyte, the absorption peak of RhB was wide in ultraviolet range indicating the typical benzene rings absorption peak in polar solvent for example water. When the concentration of electrolyte was high $(\geq 0.01 \mathrm{~mol} / \mathrm{L})$, beside the sharply decrease of absorption at $554 \mathrm{~nm}$ and the blue shift, the absorption peak of $\mathrm{RhB}$ in ultraviolet range was divided into two peaks near 230 and $290 \mathrm{~nm}$ that were the typical absorption peaks of pyrocatechol salts (Tyson and Martell, 1968). These phenomenon means the chromophore structure in $\mathrm{RhB}$ had been destroyed in electrolyte with high concentration.

The presence of cations and the positive surface of $\mathrm{TiO}_{2}$ particles might lead to the obvious different results between this study and literatures mentioned before. As shown in Fig. 5, there were still absorbing peaks near $290 \mathrm{~nm}$ 


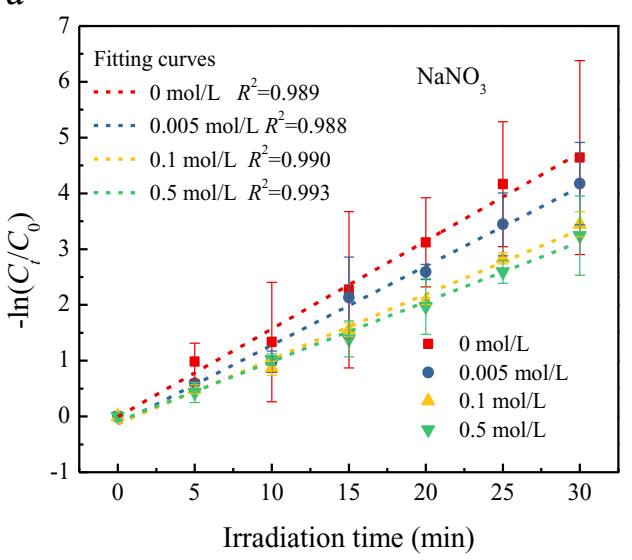

$\mathrm{c}$

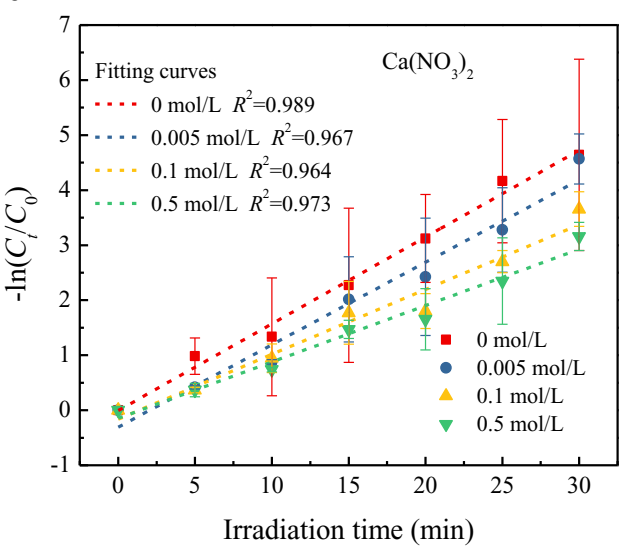

b

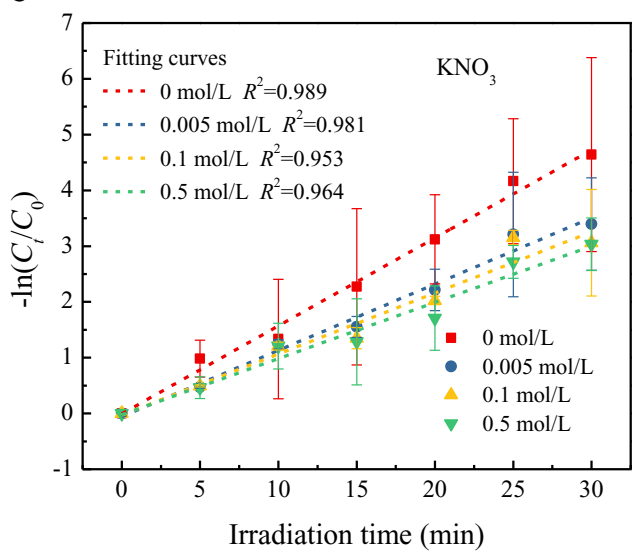

d

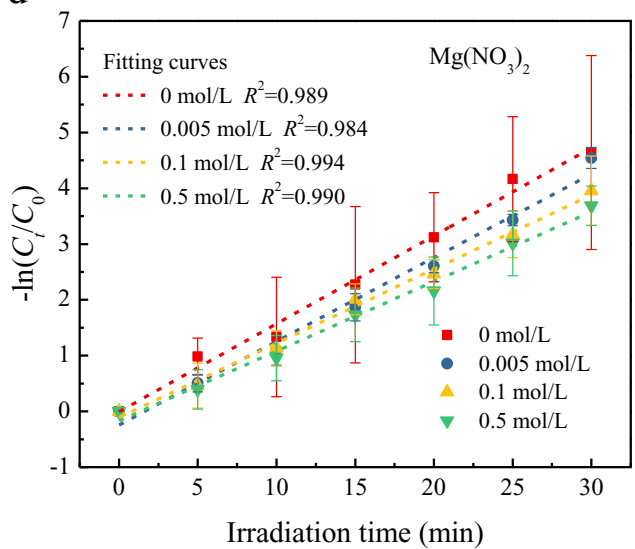

e

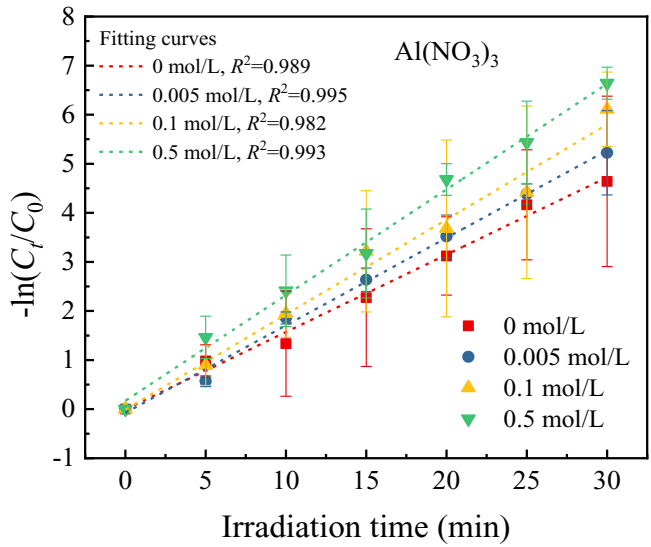

Fig. 4 - Reaction rate kinetics at different contents in the presence of (a) $\mathrm{NaNO}_{3}$, (b) $\mathrm{KNO}_{3}$, (c) $\mathrm{Ca}\left(\mathrm{NO}_{3}\right)_{2}$, (d) $\mathrm{Mg}\left(\mathrm{NO}_{3}\right)_{2}$, and (e) $\mathrm{Al}$ $\left(\mathrm{NO}_{3}\right)_{3} \cdot \mathrm{R}^{2}$ : the coefficients of determination; $\mathrm{C}_{0}(\mathrm{~g} / \mathrm{L})$ : the initial absorption of $\mathrm{RhB}$ at $554 \mathrm{~nm}$ before the illumination; $\mathrm{C}_{\mathrm{t}}(\mathrm{g} / \mathrm{L})$ : the absorption of $\mathrm{RhB}$ at $554 \mathrm{~nm}$ at different illumination time.

when the UV light was turned off with high content $(>0.01 \mathrm{~mol} / \mathrm{L})$ of the $\mathrm{Al}^{3+} . \mathrm{RhB}$ is a typical ionic dye (Das and Bhattacharyya, 2014), in aqueous solution, RhB molecule has both anionic group $\mathrm{COO}^{-}$, cationic $\mathrm{N}\left(\mathrm{C}_{2} \mathrm{H}_{5}\right)_{2}^{+}$, and $\mathrm{Cl}^{-}$ (one $\mathrm{RhB}$ molecule contains one $\mathrm{Cl}^{-}$). Without the disturbance of impurity cations, RhB molecule may absorb on the surface of $\mathrm{TiO}_{2}$ particles in hydrosol by $\mathrm{COO}^{-}$and $\mathrm{Cl}^{-}$via Coulomb force. However, in the presence of electrolytes with high content $(>0.01 \mathrm{~mol} / \mathrm{L})$, the cations may partly break the structure of $\mathrm{RhB}$ molecule by combining with $\mathrm{COO}^{-}$, which lead to the increase of the absorption peak of benzene rings. In the presence of $\mathrm{Al}^{3+}$, the absorption peak of benzene rings is higher than that of other cations because of the greater Coulomb force between $\mathrm{Al}^{3+}$ and $\mathrm{COO}^{-}$. Besides, it is easily understood that there may be competitive absorption between $\mathrm{RhB}$ molecules and anion 


\begin{tabular}{|c|c|c|c|c|c|}
\hline Content $(\mathrm{mol} / \mathrm{L})$ & $\mathrm{NaNO}_{3}$ & $\mathrm{KNO}_{3}$ & $\begin{array}{c}\mathrm{Ca} \\
\left(\mathrm{NO}_{3}\right)_{2}\end{array}$ & $\begin{array}{c}\mathrm{Mg} \\
\left(\mathrm{NO}_{3}\right)_{2}\end{array}$ & $\begin{array}{c}\mathrm{Al} \\
\left(\mathrm{NO}_{3}\right)_{3}\end{array}$ \\
\hline 0 & 0.158 & 0.158 & 0.158 & 0.158 & 0.158 \\
\hline 0.005 & 0.142 & 0.119 & 0.150 & 0.150 & 0.178 \\
\hline 0.1 & 0.116 & 0.109 & 0.118 & 0.133 & 0.194 \\
\hline 0.5 & 0.107 & 0.101 & 0.102 & 0.125 & 0.215 \\
\hline
\end{tabular}

$\left(\mathrm{NO}_{3}^{-}\right)$on the positive surface of $\mathrm{TiO}_{2}$ particles of hydrosol, which may inhibit the degradation rate of RhB. Unfortunately, these explanations seem not to be able to explain the enhance effect of $\mathrm{Al}^{3+}$ on the process of $\mathrm{TiO}_{2}$ hydrosol degrading $\mathrm{RhB}$. Therefore, the role of $\mathrm{Al}^{3+}$ on the photocatalytic activity of $\mathrm{TiO}_{2}$ hydrosol needs further discussion, which is presented in Section 2.4.4.

\subsubsection{Explanations in terms of $\mathrm{pH}$ and the dispersion stability of} $\mathrm{TiO}_{2}$

The $\mathrm{pH}$ and dissolved ionic solutes play crucial roles on dispersion stability of nano $\mathrm{TiO}_{2}$ in engineered and natural systems. These parameters can be controlled in laboratory settings but they may vary spatially and temporally in practice. Spatial heterogeneity of minerals in the subsurface alters the concentration of ionic species present in different systems (e.g., groundwater versus surface water). Variation in aquatic environment $\mathrm{pH}$ stems from the same phenomenon (Mao et al., 1991). In some specific environment, like concrete pore solution, the high contents of some inorganic ions and high $\mathrm{pH}$ may affect the dispersion stability of $\mathrm{TiO}_{2}$ if adding the nano $\mathrm{TiO}_{2}$ in the concrete by mixing water. Thus, a better understanding of how $\mathrm{pH}$ and dissolved ionic solutes affect the photocatalytic behavior of $\mathrm{TiO}_{2}$ in the aqueous environment is needed.

In most of studies on the dispersion stability of nano $\mathrm{TiO}_{2}$ powders in aqueous system, due to the $\mathrm{pH}$ of tested solutions was controlled by added extra acid and alkaline solution, the influence of inorganic cations on the change of $\mathrm{pH}$ was ignored. In this study, the change of $\mathrm{pH}$ in the tested solutions was mainly caused by adding different amount of the studied cations. From the results shown in Fig. 4 and Table 1, the relationship between the $\mathrm{pH}$ and the $k_{\text {app }}$ was derived. In addition, the results were shown in Fig. 6, it could be seen that the $k_{\text {app }}$ was linear with the $\mathrm{pH}$ of the solution, and $\mathrm{R}^{2}$ was 0.954, indicating the very good relativity. The photodegradation rate decreased with the increase of $\mathrm{pH}$ of the solution. Yu et al. (2012) had studied photo-degradation rate of Methylene Blue by $\mathrm{TiO}_{2}$ hydrosol with different solution $\mathrm{pH}$ (adjusted by $\mathrm{HNO}_{3}$ solution) under sunlight irradiation, and the results showed that hydrosol with $\mathrm{pH}$ ranging from 1 to 4 all had high photocatalytic activity toward Methylene Blue, and the photo-degradation rate was higher with lower $\mathrm{pH}$. Although the dispersion stability of nano $\mathrm{TiO}_{2}$ particles was directly related to the $\mathrm{pH}$ of system, the causes of the change of $\mathrm{pH}$ need further study, for example the presence of inorganic cations studied in this work.

From Figs. 2 and 3, it can be seen that the variation trend of the zeta potentials of $\mathrm{TiO}_{2}$ affected by the cations was intuitively similar to the particle size. $\mathrm{TiO}_{2}$ particles agglomerated significantly over time and the zeta potential also obviously increased with time, which indicated that the nano $\mathrm{TiO}_{2}$ particles showed dynamic instability with the presence of cations like $\mathrm{Na}^{+}, \mathrm{K}^{+}, \mathrm{Ca}^{2+}$ and $\mathrm{Mg}^{2+}$ at higher contents $(0.1$ and $0.5 \mathrm{~mol} / \mathrm{L}$ ). Moreover, $\mathrm{TiO}_{2}$ particles showed much stable zeta potentials in the presence of $\mathrm{Al}^{3+}$ with the same contents, and the $\mathrm{TiO}_{2}$ particles increased much slower than that in other groups. These results suggested that $\mathrm{TiO}_{2}$ particles presented better dispersion stability in solutions with the presence of high content of $\mathrm{Al}^{3+}$. According to the literature data (Holmberg et al., 2013; Leroy et al., 2011), the isoelectric point of $\mathrm{TiO}_{2}$ nano particles without extra electrolytes are in a $\mathrm{pH}$ range of 5.6-6.0. When at a $\mathrm{pH}$ near 5.6-6.0, the $\mathrm{TiO}_{2}$ sols undergo coagulation that results in a relatively low ionelectrostatic repulsion barrier, which cannot terminate particles agglomeration (Volkova et al., 2012). According to Volkova et al. $(2012,2010)$, mental ions $\left(\mathrm{Na}^{+}, \mathrm{K}^{+}, \mathrm{Ba}^{2+}\right.$ and $\mathrm{La}^{3+}$ ) caused the point of zero charge (PZC) shift to the acidic region, and

Table $2-k_{\text {app }}$ for nano $\mathrm{TiO}_{2}$ powders degradation of $\mathrm{RhB}$ in literature.

\begin{tabular}{|c|c|c|c|c|c|}
\hline Catalyst & $\begin{array}{l}\text { Solid content } \\
\text { (g/L) }\end{array}$ & $\begin{array}{l}\text { Light intensity } \\
\qquad\left(\mathrm{W} / \mathrm{m}^{2}\right)\end{array}$ & $\begin{array}{c}k_{\mathrm{app}} \\
\left(\min ^{-1}\right)\end{array}$ & $\begin{array}{l}\text { Half period of } \mathrm{RhB} \\
\text { degradation (min) }\end{array}$ & Reference \\
\hline Nano $\mathrm{TiO}_{2}$ powder suspension & 10 & 450 & 0.0658 & 10.53 & Asilturk et al. (2006) \\
\hline Nano $\mathrm{TiO}_{2}$ powder & 2 & Not mentioned & 0.00793 & 87.41 & $\begin{array}{l}\text { Pang and Abdullah } \\
\text { (2012) }\end{array}$ \\
\hline $\mathrm{TiO}_{2}$ nanotubes & 2 & Not mentioned & 0.03271 & 21.19 & $\begin{array}{l}\text { Pang and Abdullah } \\
\text { (2012) }\end{array}$ \\
\hline $\mathrm{TiO}_{2}$ nanotubes + ultrasonic & 2 & Not mentioned & 0.005 & 138.63 & Pang et al. (2011) \\
\hline Nano $\mathrm{TiO}_{2}$ powder & 2 & Not mentioned & 0.005 & 138.63 & Song et al. (2012) \\
\hline Nano $\mathrm{TiO}_{2}$ powder & 1 & $3.6 \times 10^{5}$ & 0.0165 & 42.01 & $\begin{array}{l}\text { Priya and Madras } \\
\text { (2006) }\end{array}$ \\
\hline P25 & 1 & $3.6 \times 10^{5}$ & 0.0114 & 60.80 & $\begin{array}{l}\text { Priya and Madras } \\
\text { (2006) }\end{array}$ \\
\hline Nano $\mathrm{TiO}_{2}$ coated activated carbon & 2.5 & $1.8 \times 10^{4}$ & 0.0207 & 33.49 & Zhang et al. (2011) \\
\hline $\mathrm{TiO}_{2}$ nanodispersed hydrosol & 0.02 & 349 & 0.158 & 4.39 & This study \\
\hline $\begin{array}{l}\mathrm{TiO}_{2} \text { nanodispersed } \\
\text { hydrosol + } 0.5 \mathrm{~mol} / \mathrm{L} \mathrm{Al}^{3+}\end{array}$ & 0.02 & 349 & 0.215 & 3.22 & This study \\
\hline
\end{tabular}



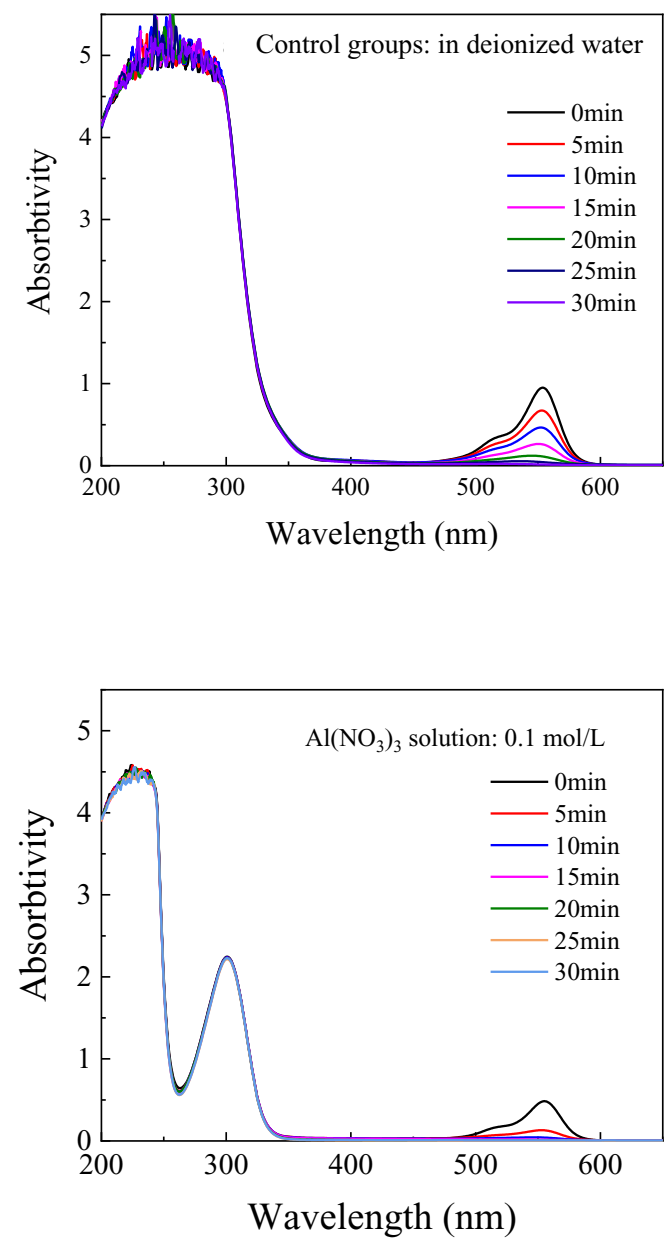
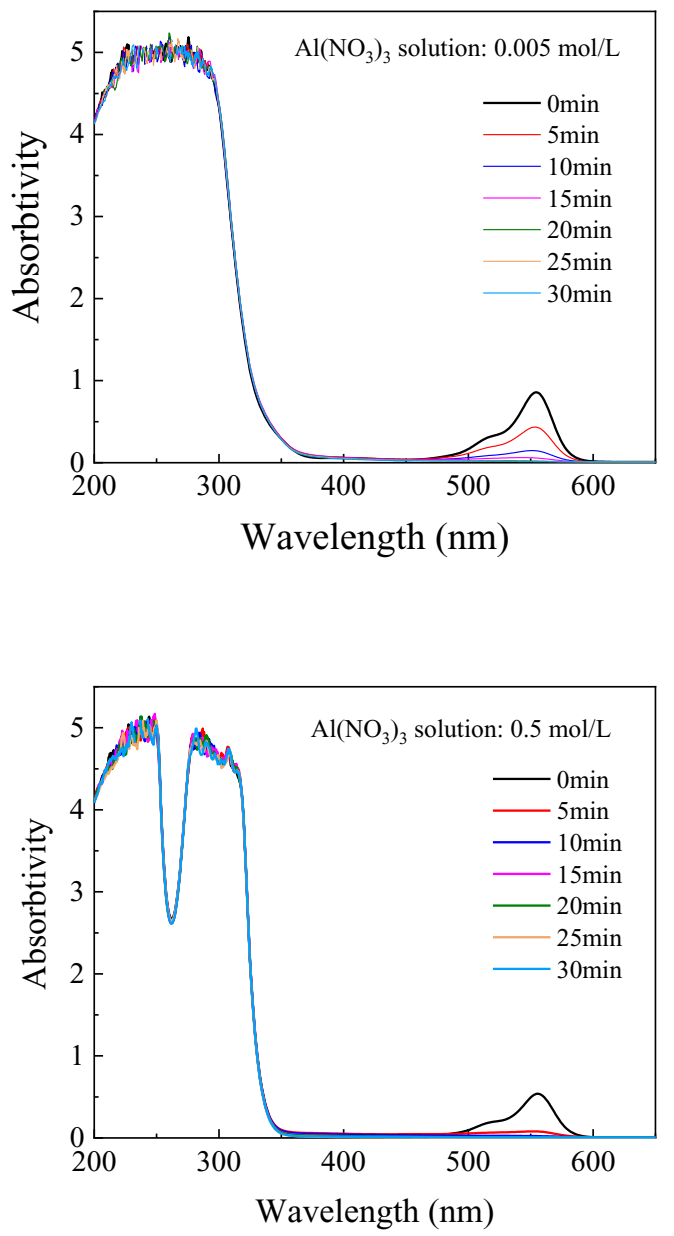

Fig. 5 - Absorption spectra of $\mathrm{RhB}$ with $\mathrm{TiO}_{2}$ hydrosol under ultreviolet (UV) light irradiation without cations (Control groups) and in the presence of $0.005,0.1$, and $0.5 \mathrm{~mol} / \mathrm{L} \mathrm{Al}^{3+}$.

the single charge anions $\left(\mathrm{Cl}^{-}, \mathrm{Br}^{-}\right.$and $\left.\mathrm{I}^{-}\right)$did not affect the surface charge of anatase $\mathrm{TiO}_{2}$ and the position in solutions of 1:1 background electrolytes. These may additionally explain the agglomeration of $\mathrm{TiO}_{2}$ particles in large dosage of nitrates with $\mathrm{Na}^{+}, \mathrm{K}^{+}, \mathrm{Ca}^{2+}, \mathrm{Mg}^{2+}$ and $\mathrm{Al}^{3+}$. In addition, in literature

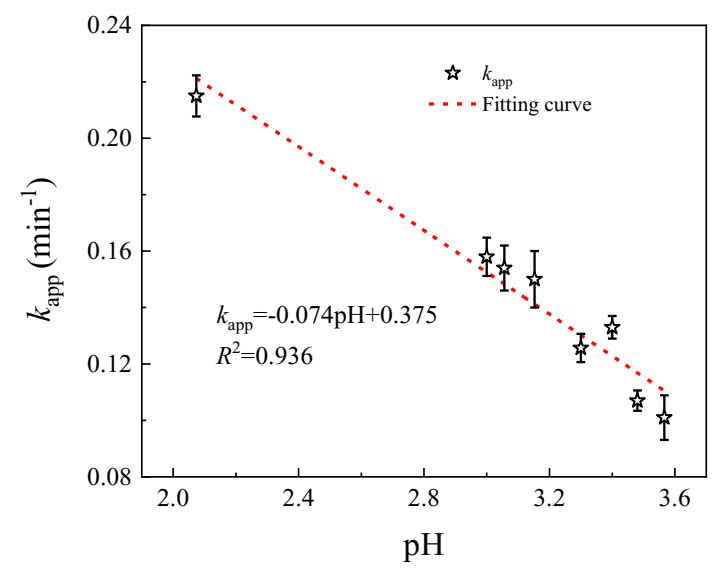

Fig. 6 - Relationship between $k_{\text {app }}$ and the $\mathrm{pH}$ of solutions.
(Volkova et al., 2012, 2010), compared with other low valance cations the higher valence of $\mathrm{La}^{3+}$ caused the worst agglomeration of $\mathrm{TiO}_{2}$ sol and the greatest PZC shifting at the presence of $0.1 \mathrm{~mol} / \mathrm{L} \mathrm{La}^{3+}$. However, in this study, $\mathrm{Al}^{3+}$, which was also a cation with high valence, caused little coagulation of $\mathrm{TiO}_{2}$ hydrosol and enhanced the photocatalytic performance of $\mathrm{TiO}_{2}$.

According to the above analysis in this section, the negative influence of $\mathrm{Na}^{+}, \mathrm{K}^{+}, \mathrm{Ca}^{2+}, \mathrm{Mg}^{2+}$ on the photocatalytic performance might be explained by exacerbating the competitive absorption among RhB molecule and anions on the surface of $\mathrm{TiO}_{2}$. The competitive absorption led to the unstable surface charge of the $\mathrm{TiO}_{2}$ surface and resulted in the agglomeration and lower photodegradation of $\mathrm{RhB}$. However, the acceleration of $\mathrm{Al}^{3+}$ on the photocatalytic performance of $\mathrm{TiO}_{2}$ cannot be explained by these explanations. In the following section, we were trying to explain the role of $\mathrm{Al}^{3+}$ on the photocatalytic activity of $\mathrm{TiO}_{2}$ hydrosol in degrading $\mathrm{RhB}$.

2.4.4. Role of $\mathrm{Al}^{3+}$ on the photocatalytic activity of $\mathrm{TiO}_{2}$ hydrosol The UV-light induced $\mathrm{TiO}_{2}$ photocatalytic reaction mechanism was well studied by many researchers (Hoffmann et al., 1995; Kamat, 1993; Ma et al., 2019, 2018; Wang et al., 2018). Based on the previous analysis, Fig. 7 shows the probable 


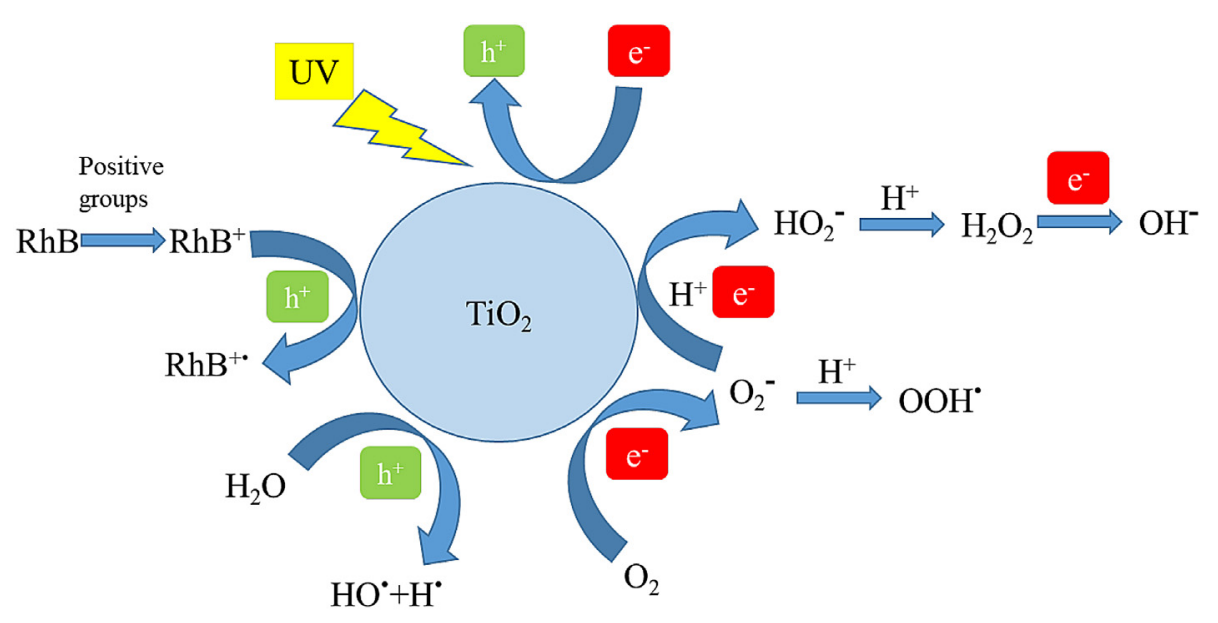

Fig. 7 - Photocatalytic reactions of $\mathrm{TiO}_{2}$ for degrading $\mathrm{RhB} . \mathrm{h}^{+}$: holes; $\mathrm{e}^{-}$: electrons.

degradation process of $\mathrm{RhB}$ in the studied system of this study. It is clear that $\mathrm{H}^{+}$plays a significant role in the photooxidation process. The higher concentration of $\mathrm{H}^{+}$is favored for accelerating the reduction reaction and hindering the recombination of holes $\left(\mathrm{h}^{+}\right)$and electrons $\left(\mathrm{e}^{-}\right)$of $\mathrm{TiO}_{2}$ surface inspired by UV light.

In general, the transformations and distributions of $\mathrm{Al}^{3+}$ are very complicated in aqueous solution because of the hydrolytic action. The hydrolytic form of $\mathrm{Al}^{3+}$ in water can be divided into three types, the monomeric hydroxyl group, the polymeric hydroxyl group, the colloidal polymerization form or amorphous aluminum hydroxide sol. $\mathrm{Al}^{3+}$ also show amphoteric characteristics in aquatic systems. In addition, the species distribution of aluminum hydrolysates varies with the $\mathrm{pH}$ value of solutions. The hydroxy aluminum complex ions in water tend to polymerize strongly to form dimer, oligomer, and hyper-polymer (Hiradate et al., 1998; Phillips et al., 2000). In the aquatic environment, aluminum is colloidal poly-aluminum hydroxide under the normal $\mathrm{pH}$. The aluminum can convert into soluble hydroxyl polymerized aluminum with the decrease of $\mathrm{pH}$ value:

$p \mathrm{Al}^{3+}+q \mathrm{H}_{2} \mathrm{O} \rightarrow \mathrm{Al}_{p}(\mathrm{OH})_{q}^{(3 p-q)+}+q \mathrm{H}^{+}$

where, $p(1 \leq p \leq 24)$ and $q(1 \leq q \leq 60)$ are stoichiometric numbers (Akitt and Elders, 1988). The hydrolytic polymerization forms of aluminum are a series of metastable states (poly (hydroxo) species) from $\mathrm{Al}^{3+}$ to $\mathrm{Al}_{m}(\mathrm{OH})_{3 m}$. However, these forms can hardly coexist in the same solution, and the dominant form will vary with the conditions (Akitt and Elders, 1988).

To distinguish the effects of $\mathrm{Al}^{3+}$ and $\mathrm{H}^{+}$on the photocatalytic process of $\mathrm{TiO}_{2}$ hydrosol, the influences of $\mathrm{H}^{+}$at different $\mathrm{pH}$ values induced by acid were also studied (the detail information can be found in Appendix A Fig. S8 and Table 3). It can be seen from Table 3 that the apparent firstorder rate constant $k_{\text {app }}$ values in two groups increased with the decrease of $\mathrm{pH}$ value. The $k_{\mathrm{app}}$ of $\mathrm{TiO}_{2}$ hydrosol in the group of $\mathrm{pH}$ induced by $\mathrm{HNO}_{3}$ was smaller than that of $\mathrm{pH}$ induced by $\mathrm{Al}\left(\mathrm{NO}_{3}\right)_{3}$.

Because of the flocculation effect of the hydrolysates of aluminum, they have a strong adsorption effect on impurities in water (Van Benschoten and Edzwald, 1990; Cao et al., 2016; Tang et al., 2015). The solution pH plays an important role on the hydrolysis process of aluminum (Zhao et al., 2009), i.e. the at lower $\mathrm{pH}(<6)$, the amount of monomer aluminum and oligomeric state aluminum increase with the decrease of $\mathrm{pH}$, and the amounts of middle and high polymer state aluminums are revised. The monomer aluminum and oligomeric state aluminum could produce cohesive force in sludge flocculation (Cao et al., 2016), and the formed flocs is larger and looser so the sludge flocs can re-grow more easily after shearing. In solutions, the attractive force between the impurity particles are reduced by compressing the diffusion layer and reducing the surface potential, the adsorbed positively charged complex ions (e.g., $\mathrm{RhB}^{+}$of $\mathrm{RhB}$ ) are interconnected and agglomerated when the attractive force gains the upper hand. These flocculation of aluminum probably enhances the surface contact between $\mathrm{TiO}_{2}$ particles and $\mathrm{RhB}$ molecules in solution, which leads to the higher degradation rate and larger $k_{\mathrm{app}}$.

In brief, the existence of $\mathrm{TiO}_{2}$ hydrosol successfully creates the low pH system in solution. Moreover, according to Eq. (2), the hydrolytic action of $\mathrm{Al}^{3+}$ produces more $\mathrm{H}^{+}$into the solution that lead to a lower $\mathrm{pH}$ system, and the agglomeration of $\mathrm{TiO}_{2}$ hydrosol is relived because of the looser and easy-to-shear floc structures caused by monomer aluminum and oligomeric state aluminum. As mentioned before (Asilturk et al., 2006), the high content (1 wt.\%) of nano $\mathrm{TiO}_{2}$ suspension decreased the photodegradation rate of $\mathrm{RhB}$ because of the agglomeration and sedimentation of the $\mathrm{TiO}_{2}$ particles caused by the collision between excited state molecules and ground state molecules. Compared with results in this study, the $\mathrm{H}^{+}$ produced by $\mathrm{Al}^{3+}$ hydrolytic action promotes the photocatalytic actions of nanodispersed $\mathrm{TiO}_{2}$ hydrosol notably, which may buffer the collision between $\mathrm{TiO}_{2}$ molecules in different

Table $3-k_{\text {app }}\left(\mathrm{min}^{-1}\right)$ at different $\mathrm{pH}$ induced by $\mathrm{HNO}_{3}$ and $\mathrm{Al}\left(\mathrm{NO}_{3}\right)_{3}$.

\begin{tabular}{lccc}
\multicolumn{1}{c}{$\mathrm{pH}$} & 3.1 & 2.9 & 2.1 \\
\hline Induced by $\mathrm{HNO}_{3}$ & 0.154 & 0.172 & 0.196 \\
Induced by $\mathrm{Al}\left(\mathrm{NO}_{3}\right)_{3}$ & 0.178 & 0.194 & 0.215 \\
\hline
\end{tabular}


states. Moreover, the hydroxy aluminum groups have a higher valence that can break the $\mathrm{RhB}$ molecule by absorbing $\mathrm{COO}^{-}$. Hence, the photo-induced degradation rate of $\mathrm{RhB}$ increased in the presence of $\mathrm{Al}^{3+}$ in $\mathrm{TiO}_{2}$ dispersed hydrosol.

\section{Conclusions}

The effect of five inorganic electrolytes in the concentration range of 0.005 to $0.5 \mathrm{~mol} / \mathrm{L}$ on the photocatalytic degradation rate $\mathrm{RhB}$ solution by $\mathrm{TiO}_{2}$ hydrosol was investigated. The relationship between photocatalysis, coagulation of $\mathrm{TiO}_{2}$ hydrosol and cations was evaluated. Firstly, the effects of cations on the photocatalytic activity of $\mathrm{TiO}_{2}$ hydrosol were discussed from the angle of the change of photocatalytic reaction kinetics. Secondly, the influences of cations on the UV-Vis absorption spectra of RhB were discussed from the view of the interaction between ions. Thirdly, the relationships between $\mathrm{TiO}_{2}$ dispersion stability and $\mathrm{pH}$ of solution caused by cation contents and types were discussed. The enhancement mechanism of $\mathrm{Al}^{3+}$ on the photocatalytic performance of $\mathrm{TiO}_{2}$ hydrosol was studied specially.

The presence of monovalent and bivalent, like $\mathrm{Na}^{+}, \mathrm{K}^{+}, \mathrm{Ca}^{2+}$ and $\mathrm{Mg}^{2+}$, inhibited $\mathrm{RhB}$ degradation and the inhibition effect increased with the increased concentration of cations because of exacerbating the competitive absorption among RhB molecule and anions on the surface of $\mathrm{TiO}_{2}$. Due to the higher valence, the negative effects of $\mathrm{Ca}^{2+}$ and $\mathrm{Mg}^{2+}$ were greater than that of monovalent. The reaction kinetic constants of the pseudo-first-order reaction kinetics model were linearly inversely proportional to the $\mathrm{pH}$ value of solutions with cations, revealing the photocatalytic performance of $\mathrm{TiO}_{2}$ hydrosols would be enhanced when containing hydrolysable cations like aluminum. Due to the hydrolytic effect of $\mathrm{Al}^{3+}$ in electrolytes, the risk of agglomeration of $\mathrm{TiO}_{2}$ particles in hydrosol was reduced; the photochemical reactivity of $\mathrm{TiO}_{2}$ hydrosol was improved, resulting in enhanced reaction rate. In the presence of $0.5 \mathrm{~mol} / \mathrm{L} \mathrm{Al}^{3+}$, the apparent first-order rate constant was $0.215 \mathrm{~min}^{-1}$, and the half period of $\mathrm{RhB}$ degradation (the time of degrading $50 \% \mathrm{RhB}$ ) was $3.22 \mathrm{~min}$. The results in this study revealed different mechanism about the coagulation of $\mathrm{TiO}_{2}$ hydrosols in electrolyte with hydrolysable mental ions. The acidic shift of point of zero charge caused by electrolytes could be partially offset by the hydrolytic action of $\mathrm{Al}^{3+}$ in the examined systems. Therefore, the coagulation of $\mathrm{TiO}_{2}$ particles could be hammered and the stability of $\mathrm{TiO}_{2}$ sols was consequently improved. These results supported that the nanodispersed $\mathrm{TiO}_{2}$ hydrosol was suitable to be used as photocatalyst in the environment containing $\mathrm{Al}^{3+}$, like urban sewage and Portland cement-like ionic environment.

\section{Acknowledgment}

This work was supported by the National Natural Science Foundation of China (Nos. 1706222, 51708108 and 51808188), the China Scholarship Council (No. 201806090146), China
Postdoctoral Science Foundation (No. 2018M642151) and State Key Laboratory of High Performance Civil Engineering Materials Open Fund (No. 2018CEM001).

\section{Appendix A. Supplementary data}

Supplementary data to this article can be found online at https://doi.org/10.1016/j.jes.2019.07.013.

\section{R E F E R E N C E S}

Abbas, Z., Holmberg, J.P., Hellström, A.K., Hagström, M., Bergenholtz, J., Hassellöv, M., et al., 2011. Synthesis, characterization and particle size distribution of $\mathrm{TiO}_{2}$ colloidal nanoparticles. Colloid. Surf. A 384, 254-261.

Akitt, J.W., Elders, J.M., 1988. Multinuclear magnetic resonance studies of the hydrolysis of aluminium(III). Part 8. Base hydrolysis monitored at very high magnetic field. J. Chem. Soc. Dalt. Trans 1347-1355.

Alphonse, P., Varghese, A., Tendero, C., 2010. Stable hydrosols for $\mathrm{TiO}_{2}$ coatings. J. Sol-Gel Sci. Technol. 56, 250-263.

Asilturk, M., Sayılkan, F., Erdemoglu, S., Akarsu, M., Sayılkan, H., Erdemoglu, M., et al., 2006. Characterization of the hydrothermally synthesized nano- $\mathrm{TiO}_{2}$ crystallite and the photocatalytic degradation of Rhodamine B. J. Hazard. Mater. B129, 164-170.

Bahnemann, D., 2004. Photocatalytic water treatment: solar energy applications. Sol. Energy 77, 445-459.

Brunelli, A., Pojana, G., Callegaro, S., Marcomini, A., 2013. Agglomeration and sedimentation of titanium dioxide nanoparticles $\left(n-\mathrm{TiO}_{2}\right)$ in synthetic and real waters. J. Nanopart. Res. $15,1684$.

Budarz, J., Turolla, A., Piasecki, A.F., 2017. Influence of aqueous inorganic anions on the reactivity of nanoparticles in $\mathrm{TiO}_{2}$ photocatalysis. Langmuir 33, 2770-2779.

Cao, B., Zhang, W., Wang, Q., Huang, Y., Meng, C., Wang, D., 2016. Wastewater sludge dewaterability enhancement using hydroxyl aluminum conditioning: role of aluminum speciation. Water Res. 105, 615-624.

Chen, J., Poon, C.-S., 2009. Photocatalytic construction and building materials: from fundamentals to applications. Build. Environ. 44, 1899-1906.

Chen, D., Ray, A.K., 1998. Photodegradation kinetics of 4nitrophenol in $\mathrm{TiO}_{2}$ suspension. Water Res. 32, 3223-3234.

Chen, H.Y., Zahraa, O., Bouchy, M., 1997. Inhibition of the adsorption and photocatalytic degradation of an organic contaminant in an aqueous suspension of $\mathrm{TiO}_{2}$ by inorganic ions. J. Photochem. Photobiol. A Chem. 108, 37-44.

Chen, H., Nanayakkara, C.E., Grassian, V.H., 2012. Titanium dioxide photocatalysis in atmospheric chemistry. Chem. Rev. 112, 5919-5948.

Chong, M.N., Jin, B., Chow, C.W.K., Saint, C., 2010. Recent developments in photocatalytic water treatment technology: a review. Water Res. 44, 2997-3027.

Das, M., Bhattacharyya, K.G., 2014. Oxidation of Rhodamine B in aqueous medium in ambient conditions with raw and acidactivated $\mathrm{MnO}_{2}, \mathrm{NiO}, \mathrm{ZnO}$ as catalysts. J. Mol. Catal. A Chem. 391, 121-129.

Dincer, I., 2000. Renewable energy and sustainable development: a crucial review. Renew. Sust. Energ. Rev. 4, 157-175.

Đukić, A.B., Kumrić, K.R., Vukelić, N.S., Dimitrijević, M.S., Baščarević, Z.D., Kurko, S.V., et al., 2015. Simultaneous removal of $\mathrm{Pb}^{2+}, \mathrm{Cu}^{2+}, \mathrm{Zn}^{2+}$ and $\mathrm{Cd}^{2+}$ from highly acidic solutions using mechanochemically synthesized 
montmorillonite-kaolinite/ $\mathrm{TiO}_{2}$ composite. Appl. Clay Sci. 103, 20-27.

Folli, A., Pochard, I., Nonat, A., Jakobsen, U.H., Shepherd, A.M., Macphee, D.E., 2010. Engineering photocatalytic cements: understanding $\mathrm{TiO}_{2}$ surface chemistry to control and modulate photocatalytic performances. J. Am. Ceram. Soc. 93, 3360-3369.

French, R.A., Jacobson, A.R., Kim, B., Isley, S.L., Penn, R.L., Baveye, P.C., 2009. Influence of ionic strength, $\mathrm{pH}$, and cation valence on aggregation kinetics of titanium dioxide. Nanoparticles 43, 1354-1359.

Fu, H., Pan, C., Yao, W., Zhu, Y., 2005. Visible-light-induced degradation of Rhodamine $\mathrm{B}$ by nanosized $\mathrm{Bi}_{2} \mathrm{WO}_{6}$. J. Phys. Chem. B 109, 22432-22439.

Galindo, C., Jacques, P., Kalt, A., 2001. Photooxidation of the phenylazonaphthol $\mathrm{AO} 20$ on $\mathrm{TiO}_{2}$ : kinetic and mechanistic investigations. Chemosphere 45, 997-1005.

Ghenne, E., Dumont, F., Buess-Herman, C., 1998. Stability of $\mathrm{TiO}_{2}$ hydrosols synthesized by hydrolysis of titanium tetraethoxide. Colloids Surf. A Physicochem. Eng. Asp. 131, 63-67.

Hashimoto, K., Irie, H., Fujishima, A., 2005. $\mathrm{TiO}_{2}$ photocatalysis: a historical overview and future prospects. Jpn. J. Appl. Phys. 44, 8269-8285.

Hiradate, S., Taniguchi, S., Sakurai, K., 1998. Aluminum speciation in aluminum-silica solutions and potassium chloride extracts of acidic soils. Soil Sci. Soc. Am. J. 62, 630-636.

Hoffmann, M., Martin, S., Choi, W., 1995. Environmental applications of photocatalysis. Chem. Rev. 95, 69-96.

Holmberg, J.P., Ahlberg, E., Bergenholtz, J., Hassellöv, M., Abbas, Z., 2013. Surface charge and interfacial potential of titanium dioxide nanoparticles: experimental and theoretical investigations. J. Colloid Interface Sci. 407, 168-176.

Honda, R.J., Keene, V., Daniels, L., Walker, S.L., 2014. Removal of $\mathrm{TiO}_{2}$ nanoparticles during primary water treatment: role of coagulant type, dose, and nanoparticle concentration. Environ. Eng. Sci. 31, 127-134.

Hotze, E.M., Phenrat, T., Lowry, G.V., 2010. Nanoparticle aggregation: challenges to understanding transport and reactivity in the environment. J. Environ. Qual. 39, 1909.

Islam, M.S., Hossain, M.M., Islam, T.S., 2010. Effect of pH, ions and ionic strength on $\mathrm{TiO}_{2}$ - mediated photodegradation of Brilliant Orange. Dhaka Univ. J. Sci. 58, 187-190.

Jing, D., Guo, L., Zhao, L., 2010. Efficient solar hydrogen production by photocatalytic water splitting: from fundamental study to pilot demonstration. Int. J. Hydrogen Ener. 35, 7087-7097.

Kamat, P.V., 1993. Photochemistry on nonreactive and reactive (semiconductor) surfaces. Chem. Rev. 93, 267-300.

Kanna, M., Wongnawa, S., Sherdshoopongse, P., Boonsin, P., 2005. Adsorption behavior of some metal ions on hydrated amorphous titanium dioxide surface. Songklanakarin J. Sci. Technol. 27, 1017-1026.

Kansal, S.K., Singh, M., Sud, D., 2007. Studies on photodegradation of two commercial dyes in aqueous phase using different photocatalysts. J. Hazard. Mater. 141, 581-590.

Lee, B., Liaw, W., Lou, J., 1999. Photocatalytic decolorization of Methylene Blue in aqueous $\mathrm{TiO}_{2}$ suspension. Environ. Eng. Sci. 16, 165-175.

Lei, Z., Ghosh, T., Park, C., Zeda, M., Wonchun, O., 2012. Enhanced Sonocatalytic degradation of rhodamine $\mathrm{B}$ by graphene- $\mathrm{TiO}_{2}$ composites synthesized by an ultrasonic-assisted method. Chin. J. Catal. 33, 1276-1283.

Leroy, P., Tournassat, C., Bizi, M., 2011. Influence of surface conductivity on the apparent zeta potential of $\mathrm{TiO}_{2}$ nanoparticles. J. Colloid Interface Sci. 356, 442-453.

Liu, T., Li, F., Li, X., 2008. $\mathrm{TiO}_{2}$ hydrosols with high activity for photocatalytic degradation of formaldehyde in a gaseous phase. J. Hazard. Mater. 152, 347-355.

Loosli, F., Le Coustumer, P., Stoll, S., 2015. Effect of electrolyte valency, alginate concentration and $\mathrm{pH}$ on engineered $\mathrm{TiO}_{2}$ nanoparticle stability in aqueous solution. Sci. Total Environ. 535, 28-34.

Ma, D., Liu, A., Li, S., Lu, C., Chen, C., 2018. $\mathrm{TiO}_{2}$ photocatalysis for C-C bond formation. Catal. Sci. Technol. 8, 2030-2045.

Ma, D., Zhai, S., Wang, Y., Liu, A., Chen, C., 2019. $\mathrm{TiO}_{2}$ photocatalysis for transfer hydrogenation. Molecules 330-352.

Malato, S., Fernández-Ibáñez, P., Maldonado, M.I., 2009. Decontamination and disinfection of water by solar photocatalysis: recent overview and trends. Catal. Today 147, 1-59.

Mao, Y., Schoeneich, C., Asmus, K.D., 1991. Identification of organic acids and other intermediates in oxidative degradation of chlorinated ethanes on titania surfaces en route to mineralization: a combined photocatalytic and radiation chemical study. J. Phys. Chem. 95, 10080-10089.

Mills, A., Lee, S.K., 2002. A web-based overview of semiconductor photochemistry-based current commercial applications. J. Photochem. Photobiol. A Chem. 152, 233-247.

Ortelli, S., Blosi, M., Albonetti, S., Vaccari, A., Dondi, M., Costa, A.L., 2014. $\mathrm{TiO}_{2}$ based nano-photocatalysis immobilized on cellulose substrates. J. Photochem. Photobiol. A Chem. 276, 58-64.

Pang, Y.L., Abdullah, A.Z., 2012. Comparative study on the process behavior and reaction kinetics in sonocatalytic degradation of organic dyes by powder and nanotubes $\mathrm{TiO}_{2}$. Ultrason. Sonochem. 19, 642-651.

Pang, Y.L., Bhatia, S., Abdullah, A.Z., 2011. Process behavior of $\mathrm{TiO}_{2}$ nanotube-enhanced sonocatalytic degradation of Rhodamine B in aqueous solution. Sep. Purif. Technol. 77, 331-338.

Pavlova-Verevkina, O.B., Shevchuk, Y.A., Nazarov, V.V., 2003. Coagulation peculiarities and fractionation of nanodispersed titanium dioxide hydrosol. Colloid J. 65, 474-477.

Pavlova-Verevkina, O.B., Chvalun, S.N., Politova, E.D., Nazarov, V. V., Ozerina, L.A., Ozerin, A.N., 2005. Study of the stable nanocrystalline $\mathrm{TiO}_{2}$ hydrosol and its fractions. J. Sol-Gel Sci. Technol. 35, 91-97.

Pavlova-Verevkina, O.B., Ozerina, L.A., Nazarov, V.V., Surin, N.M., 2007. Electrolyte-induced destabilization of hydrosols containing uniform $\mathrm{TiO}_{2}$ nanoparticles. Colloid J. 69, 492-497.

Phillips, B.L., Casey, W.H., Karlsson, M., 2000. Bonding and reactivity at oxide mineral surfaces from model aqueous complexes. Nature 404, 379-382.

Poulios, I., Aetopoulou, I., 1999. Photocatalytic degradation of the textile dye reactive orange 16 in the presence of $\mathrm{TiO}_{2}$ suspensions. Environ. Technol. 20, 479-487.

Poulios, I., Tsachpinis, I., 1999. Photodegradation of the textile dye Reactive Black 5 in the presence of semiconducting oxides. J. Chem. Technol. Biotechnol. 74, 349-357.

Priya, M.H., Madras, G., 2006. Kinetics of $\mathrm{TiO}_{2}$-catalyzed ultrasonic degradation of Rhodamine dyes. Ind. Eng. Chem. Res. 45, 913-921.

Qu, P., Zhao, J., Shen, T., Hidaka, H., 1998. $\mathrm{TiO}_{2}$-assisted photodegradation of dyes: a study of two competitive primary processes in the degradation of $\mathrm{RB}$ in an aqueous $\mathrm{TiO}_{2}$ colloidal solution. J. Mol. Catal. A Chem. 129, 257-268.

Santacesaria, E., Tonello, M., Storti, G., Pace, R.C., Carrà, S., 1986. Kinetics of titanium dioxide precipitation by thermal hydrolysis. J. Colloid Interface Sci. 111, 44-53.

Sauer, T., Cesconeto Neto, G., José, H.J., Moreira, R.F.P.M., 2002. Kinetics of photocatalytic degradation of reactive dyes in a $\mathrm{TiO}_{2}$ slurry reactor. J. Photochem. Photobiol. A Chem. 149, 147-154.

Song, L., Zhang, S., Wu, X., Wei, Q., 2012. Synthesis of porous and trigonal $\mathrm{TiO}_{2}$ nanoflake, its high activity for sonocatalytic degradation of rhodamine B and kinetic analysis. Ultrason. Sonochem. 19, 1169-1173.

Spasiano, D., Rodriguez, L., Olleros, J., 2013. $\mathrm{TiO}_{2} / \mathrm{Cu}$ (II) photocatalytic production of benzaldehyde from benzyl alcohol in solar pilot plant reactor. Appl. Catal. B Environ. 136-137, 56-63. 
Tang, H., Xiao, F., Wang, D., 2015. Speciation, stability, and coagulation mechanisms of hydroxyl aluminum clusters formed by PACl and alum: a critical review. Adv. Colloid Interf. Sci. 226, 78-85.

Terzian, R., Serpone, N., Minero, C., Pelizzetti, E., 1991. Photocatalyzed mineralization of mresols in aqueous media with irradiated titania. J. Catal. 128, 352-365.

Tyson, C.A., Martell, A.E., 1968. Equilibria of metal ions with pyrocatechol and 3,5-di-t-butylpyrocatechol. J. Am. Chem. Soc. 90, 3379-3386.

Van Benschoten, J.E., Edzwald, J.K., 1990. Chemical aspects of coagulation using aluminum salts-I. Hydrolytic reactions of alum and polyaluminum chloride. Water Res. 24, 1519-1526.

Volkova, A.V., Ermakova, L.E., Bogdanova, N.F., Tarabukina, E.A., Sidorova, M.P., 2010. Electrosurface characteristics of titanium dioxide in solutions of simple electrolytes: I. Effect of nature of counterions on adsorption and electrokinetic parameters of $\mathrm{TiO}_{2}$. Colloid J. 72, 743-748.

Volkova, A.V., Golikova, E.V., Ermakova, L.E., 2012. Photometric study of the kinetics of $\mathrm{TiO}_{2}$ hydrosol coagulation in electrolyte solutions. Colloid J. 74, 32-37.

Wahyuningsih, S., Purnawan, C., Kartikasari, P.A., 2014. Visible light photoelectrocatalytic degradation of rhodamine B using a dye-sensitised $\mathrm{TiO}_{2}$ electrode. Chem. Pap. 68, 1248-1256.

Wang, F., Zhang, K., 2011. Reduced graphene oxide $-\mathrm{TiO}_{2}$ nanocomposite with high photocatalystic activity for the degradation of rhodamine B. J. Mol. Catal. A Chem. 345, 101-107.

Wang, J., Liu, Z., Cai, R., 2008. A new role for $\mathrm{Fe}^{3+}$ in $\mathrm{TiO}_{2}$ hydrosol: accelerated photodegradation of dyes under visible light. Environ. Sci. Technol. 42, 5759-5764.

Wang, J., Jiang, Z., Zhang, L., Kang, P., Xie, Y., Lv, Y., et al., 2009. Ultrasonics sonochemistry sonocatalytic degradation of some dyestuffs and comparison of catalytic activities of nano-sized $\mathrm{TiO}_{2}$, nano-sized $\mathrm{ZnO}$ and composite $\mathrm{TiO}_{2} / \mathrm{ZnO}$ powders under ultrasonic irradiation. Ultrason. Sonochem. 16, 225-231.

Wang, Y., Liu, A., Ma, D., Li, S., Lu, C., Li, T., et al., 2018. $\mathrm{TiO}_{2}$ Photocatalyzed $\mathrm{C}-\mathrm{H}$ bond transformation for $\mathrm{C}-\mathrm{C}$ coupling reactions. Catalysts 8,355 .

Wu, T., Liu, G., Zhao, J., Hidaka, H., Serpone, N., 1998. Photoassisted degradation of dye pollutants. V. Selfphotosensitized oxidative transformation of Rhodamine $B$ under visible light irradiation in aqueous $\mathrm{TiO}_{2}$ dispersions. J. Phys. Chem. B 102, 5845-5851.
Xu, H., Xiao, F., Wang, D., 2014. Effects of $\mathrm{Al}_{2} \mathrm{O}_{3}$ and $\mathrm{TiO}_{2}$ on the coagulation process by $\mathrm{Al}_{2}\left(\mathrm{SO}_{4}\right)_{3}$ (AS) and poly-aluminum chloride (PACl) in kaolin suspension. Sep. Purif. Technol. 124, 9-17.

Yang, H., Li, G., An, T., 2010. Photocatalytic degradation kinetics and mechanism of environmental pharmaceuticals in aqueous suspension of $\mathrm{TiO}_{2}$ : a case of b-blockers. Catal. Today 153, 200-207.

Yousefi, A., Allahverdi, A., Hejazi, P., 2013. Effective dispersion of nano- $\mathrm{TiO}_{2}$ powder for enhancement of photocatalytic properties in cement mixes. Constr. Build. Mater. 41, 224-230.

Yu, J.X., Chi, R.A., Su, X.Z., He, Z.Y., Qi, Y.F., Zhang, Y.F., 2010. Desorption behavior of methylene blue on pyromellitic dianhydride modified biosorbent by a novel eluent: acid $\mathrm{TiO}_{2}$ hydrosol. J. Hazard. Mater. 177, 222-227.

Yu, J.X., Chi, R.A., Guo, J., 2012. Desorption and photodegradation of methylene blue from modified sugarcane bagasse surface by acid $\mathrm{TiO}_{2}$ hydrosol. Appl. Surf. Sci. 258, 4085-4090.

Zhang, Y., Chen, Y., Westerhoff, P., Crittenden, J., 2009. Impact of natural organic matter and divalent cations on the stability of aqueous nanoparticles. Water Res. 43, 4249-4257.

Zhang, W., Li, Y., Wang, C., Wang, P., 2011. Kinetics of heterogeneous photocatalytic degradation of rhodamine $\mathrm{B}$ by $\mathrm{TiO}_{2-}$ coated activated carbon: roles of $\mathrm{TiO}_{2}$ content and light intensity. Desalination 266, 40-45. https://doi.org/10.1016/j. desal.2010.07.066.

Zhang, J., Jiang, P., Sun, P., Wang, Q., Kuang, J., Liu, W., et al., 2018. Role of ammonium ions on the stability of $\mathrm{TiO}_{2}$ sol. J. Dispers. Sci. Technol. 2691, 1-6.

Zhao, J., Wu, T., Wu, K., Oikawa, K., Hisao, H., Serpone, N., 1998. Photoassisted degradation of dye pollutants. 3. Degradation of the cationic dye Rhodamine B in aqueous anionic surfactant/ $\mathrm{TiO}_{2}$ dispersions under visible light irradiation: evidence for the need of substrate adsorption on $\mathrm{TiO}_{2}$ part. Environ. Sci. Technol. 32, 2394-2400.

Zhao, C., Zhang, J., Luan, Z., Peng, X., Ren, X., 2009. Preparation of high concentration polyaluminum chloride with high content of $\mathrm{Al}_{\mathrm{b}}$ or $\mathrm{Al}_{\mathrm{c} .}$. J. Environ. Sci. 21, 1342-1346.

Zhu, L., Jo, S.B., Ye, S., Ullah, K., Oh, W.C., 2014. Rhodamine B degradation and reactive oxygen species generation by a ZnSegraphene/ $\mathrm{TiO}_{2}$ sonocatalyst. Chin. J. Catal. 35, 1825-1832. 